\title{
A CLOSER LOOK AT ŠVENTOJI 2/4 - A STRATIFIED STONE AGE FISHING SITE IN COASTAL LITHUANIA, 3200-2600 CAL BC
}

\author{
GYTIS PILIČIAUSKAS ${ }^{1}$, GIEDRĖ VAIKUTIENE் ${ }^{2}$, DALIA KISIELIENÉ ${ }^{3}$, \\ ALDONA DAMUŠYTE் ${ }^{4}$, GIEDRĖ PILIČIAUSKIENE் ${ }^{5}$, KĘSTUTIS PESECKAS ${ }^{6}$, \\ LUKAS GAIŽAUSKAS
}

\footnotetext{
${ }^{1}$ Department of Archaeology, Lithuanian Institute of History, Kražiu 5, 01108 Vilnius, Lithuania, e-mail: gytis.piliciauskas@gmail.com

${ }^{2}$ Institute of Geosciences, Vilnius University, M. K. Čiurlionio 21/27, 03101 Vilnius, Lithuania,

e-mail: giedre.vaikutiene@gf.vu.lt

${ }^{3}$ Laboratory of Quaternary Research, Nature Research Centre, Akademijos 2, 08412 Vilnius, Lithuania,

e-mail: dalia.kisieliene@gamtc.lt

${ }^{4}$ Lithuanian Geological Survey, S. Konarskio 35, 03123 Vilnius, Lithuania, e-mail: aldona.damusyte@lgt.lt

${ }^{5}$ Department of Archaeology, Vilnius University, Universiteto 7, 01513 Vilnius, Lithuania, e-mail: giedrepils@gmail.com

${ }^{6}$ Laboratory of Nuclear Geophysics and Radioecology, Geology and Geography Institute, Nature Research Centre, Akademijos 2, 08412 Vilnius, Lithuania, e-mail: kestas@utgardas.lt

${ }^{7}$ Laboratory of Bedrock Geology, Nature Research Centre, Akademijos 2, 08412 Vilnius, Lithuania,

e-mail: lukas.gaizauskas0@gmail.com
}

Šventoji 2/4, which is situated on the Lithuanian coast, is among the most important East Baltic Stone Age sites due to the extraordinary preservation of archaeological finds in waterlogged gyttja and due to extensive excavations ongoing since 1967. This paper presents the results of excavations in 2014 and subsequent laboratory analyses. This new research has allowed for the revision of the site's chronology and function as well as provided valuable environmental data. In 3200-2700 cal BC the site was used as a fishing station constructed in the deepest part of the shallow lagoonal lake. Remains of various fishing gear and other human waste left during fishing expeditions accumulated there. Enormous amounts of cranial fish bones left during the initial processing of the catch that was carried out directly at the fishery indicate that cyprinids, pike, and zander were mostly caught at the site. The site most likely continued to be used in similar way during the beginning of the Neolithic, although Globular Amphora culture fishermen did not process fish on the site and transported the entire catch to dwelling sites instead.

Keywords: Subneolithic, Neolithic, coastal Lithuania, fishing, environment.

Šventosios 2/4 radimvietè Lietuvos pajūryje yra viena iš svarbiausių Rytų Baltijos regiono akmens amžiaus vietoviu dèl ypač gerai šlapiose ežerinèse nuosèdose išlikusiu archeologiniu radiniu ir plačiu archeologiniu kasinèjimu, vykstančiu nuo $1967 \mathrm{~m}$. Šis straipsnis pristato $2014 \mathrm{~m}$. kasinejjimu ir rastos medžiagos laboratorinių tyrimu rezultatus, kurie patikslino radimvietès chronologija ir funkciją, suteikè vertingu žiniu apie gamtine jos aplinką. Pagal mūsu tyrimu rezultatus, tai buvusi $\check{z} v e j y b v i e t e$, , ikurta giliausioje lagūninio ežero dalyje ir naudota 3200-2700 cal BC. Joje kaupési ìvairios žvejybinès ịrangos dalys, taip pat kitu veiklu atliekos, išmestos vandenin žvejojant. Daugybe gèlavandeniu žuvu galvos kaulu aptikta buvusio ežero dumble, nes pirminis žuvies apdorojimas vyko žvejybvietèje. Daugiausia gaudytos karpines žuvys, lydekos, sterkai. Šioje vietoje žvejota ir neolito pradžioje, tačiau Rutuliniu amforų kultūros žvejai laimikio greičiausiai nedarinèjo žvejybvietèje, o visa gabeno i gyvenvietes.

Reikšminiai žodžiai: subneolitas, neolitas, Lietuvos pajūris, žvejyba, gamtinè aplinka. 


\section{INTRODUCTION}

Šventoji $2 / 4^{1}$ is the largest among many Stone and Bronze Age sites known in the Šventoji area along the Lithuanian coast (Fig. 1). An area of about 2,300 m² was excavated at the site in $1967,1969,1972,1986-$ 1995, 1997-1998, 2002-2005, and 2014-2015 (Fig. 2; Rimantienè 1979; 1980; 1996a; 2005; Juodagalvis, Simpson 2000; Brazaitis 2007; Piličiauskas et al. 2012; Piličiauskienè et al. 2015; Kurilienè et al. 2016). Most of these excavations were driven by scientific interest in the extraordinarily well-preserved artefacts, including those made of organic materials, by the presence of a stratified cultural layer, and by the great potential for paleoenvironmental studies. The site is unique in Lithuanian archaeology due to its huge size, a unique paleolandscape with the paleochannel still visible in modern topography (Fig. 2), and millions of fish bones densely accumulated in the lake sediment. In addition to purely scientific research, hundreds of test pits were investigated in 2006 and 2015 due to prospecting for future urban development, since the area of the site currently belongs to Palanga city, which is expanding rapidly into the drained bogs, including areas that have archaeological sites.

In 2014 we launched excavations at Šventoji $2 / 4$ as a part of the project 'Neolithisation of coastal Lithuania'. Several goals were set by our interdisciplinary team. The first one was to learn more about the pottery sequence in coastal Lithuania via precise documentation of stratigraphy and finds and also an extensive radiocarbon dating programme and age modelling. Since the site contains the youngest Subneolithic ${ }^{2}$ (Porous Ware or Narva Ware according to previous classification) and the oldest Neolithic
(Globular Amphora Ware) material culture, it presents a unique opportunity to learn about the process of neolithisation of coastal ecotones in the Southeastern Baltic. Furthermore, we expected to reconstruct environmental settings and to understand the function of the site through zooarchaeological, macro-botanical, and diatom analyses. The formation of the paleochannel and its probable impact for human activities on the site needed to be explained. However, we felt unable to answer these questions by analysing previously excavated materials, mostly because of the poor documentation standards employed during older field research as well as the lack of paleoenvironmental data securely related to different phases of site exploitation. Therefore, new excavations as well as new laboratory analyses were necessary. In this paper we are presenting the results of these various studies. Only a small part of them have been already published elsewhere (Piličiauskas, Heron 2015; Piličiauskas 2016).

\section{SITE SITUATION AND DISCOVERY}

Šventoji $2 / 4$ is situated on the terrace formed by Littorina Sea during its maximal transgression ca. 5000 cal BC (Kabailienè, Rimantienè 1998; Damušytė 2011; Piličiauskas et al. 2015). The terrace extends like a band up to $4 \mathrm{~km}$ wide for $35 \mathrm{~km}$ from Pape Lake in the North to the mouth of the Rąže River in the South (Fig. 1). It is mostly composed of fine to medium sand and its surface varies between -2 and $5 \mathrm{~m}$ a.s.l. Low-lying parts of the terrace are covered with lagoonal/lacustrine (silt and gyttja) and boggy (peat) sediments up to $2.5 \mathrm{~m}$ thick and therefore are called the Pajūris bog. Gyttja cover

${ }^{1}$ At first, Šventoji 2 and 4 were treated as separate sites (Rimantiené 1979; 1980; 1996a). These sites were described together only in the latest publication by Rimantienè (2005) because it was realised they both contain the same archaeological layers and that there is no gap between them. It was found that they were previously named differently since modern the road and drainage channel artificially divided the same site into two parts (Fig. 2).

${ }^{2}$ Subneolithic $=$ pottery Mesolithic. 
formed during the regression of the sea when the littoral parts of the sea bed became isolated from the sea by sandy bars. Today the western part of the terrace, which is very close to the modern coastline, is covered by recent dunes. In some places the sandy terrace has been cut by ancient river channels with beds of varying width, dug into the marine/ lagoonal sand and silt by 1 to 2 meters and sometimes reaching the Baltic Ice Lake or even glacial deposits (Piličiauskas et al. 2012; Piličiauskas 2016).

The Pajūris bog was heavily drained during the $19^{\text {th }}$ and $20^{\text {th }}$ centuries. The final and the most extensive drainage project occurred between 1966-1967. During these construction projects, most of the Šventoji wetland sites were discovered. Šventoji 2/4, for instance, was among many wetland sites discovered by a local youth, Mikelis Balčius, who collected various Stone Age finds from heaps of excavated gyttja and from the walls of freshly dug drainage ditches. The news about these finds reached Lithuanian archaeologist Rimute Rimantienè, who soon after began extensive excavations at the site (Rimantienè 2005).

\section{FIELD RESEARCH IN 2014}

In 2014, an $18 \mathrm{~m}$ long and $2 \mathrm{~m}$ wide trench was investigated at Šventoji 2/4. It was dug on the slope of the paleochannel and oriented perpendicular to its shore. In order to obtain stratigraphic information from the whole width of the paleochannel, 9 boreholes were drilled with a soil corer $3 \mathrm{~cm}$ in diameter (Fig. 2). Since part of the archaeological layer lies below the

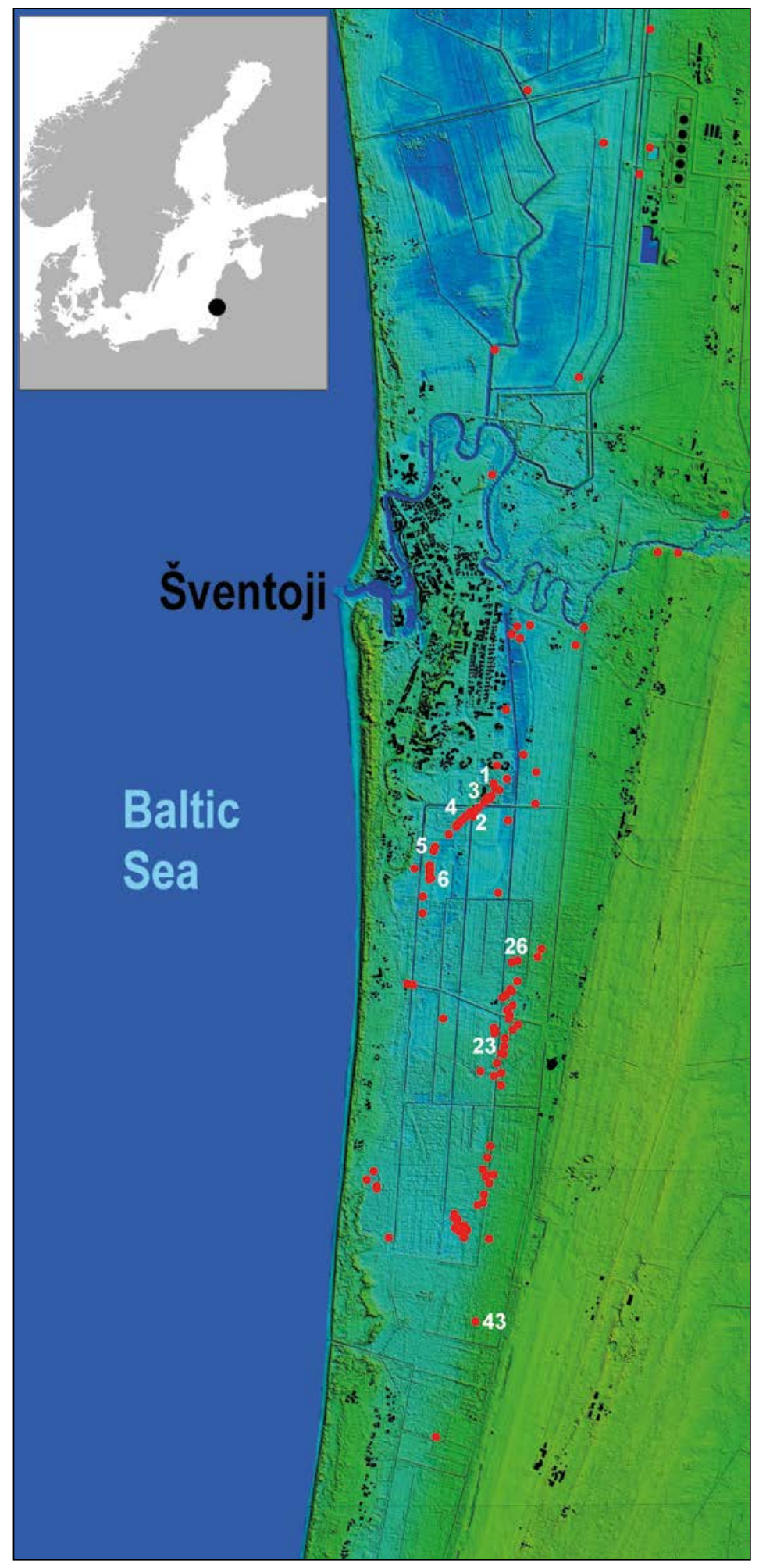

Fig. 1. Mesolithic - Bronze Age sites in Šventoji area. Drawing by G. Piličiauskas. 


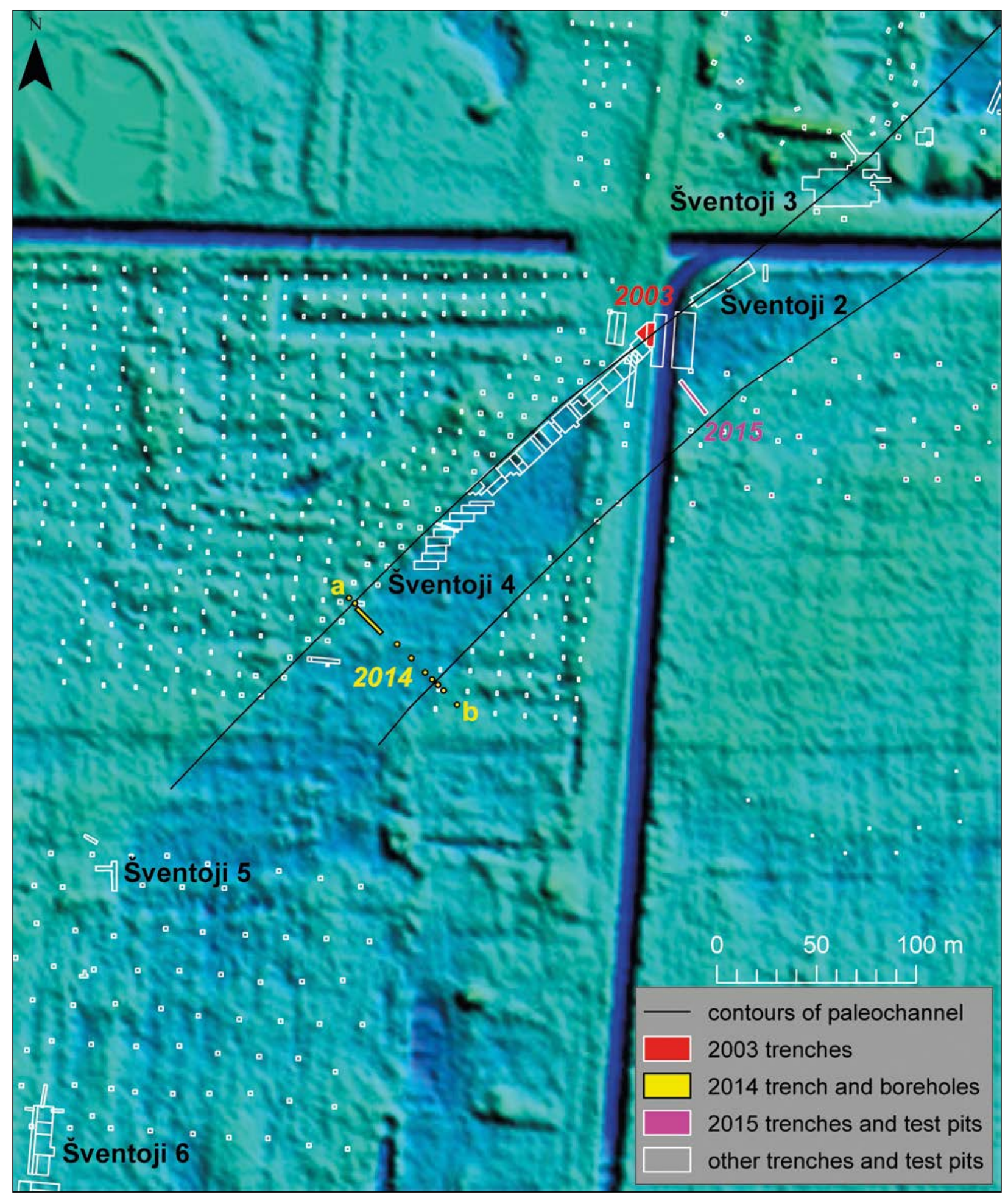

Fig. 2. Archaeological trenches, testpits, and boreholes excavated between 1967-2015 at Šventoji 2-6 sites plotted on a shaded map made using LIDAR data. Drawing by G. Piličiauskas. 
water table, a water pump (we used Honda WX15) was used to remove water collecting in the deepest end of the trench (Fig. 3).

Wet sieving of gyttja proved to be highly inefficient, and therefore, the largest part of cultural layer was excavated with trowels and most of the finds were collected by hand. However, sandy gyttja with fish bone concentrations were cut out from the sediment as soil blocks up to 0.5 meter in diameter and up to $5 \mathrm{~cm}$ thick and then wet sieved under gently flowing water through $1 \mathrm{~mm}$ mesh sieves. Spatial data of individual finds and wetsieved gyttja blocks was recorded with a total station.

\section{NATURAL STRATIGRAPHY}

Two sections of different lengths and resolution were studied in order to understand the site's formation and chronology. Firstly, we recorded a section 18 meters long within the excavated trench and recorded the exact position of various finds and sampling spots (Fig. 4). Later this section was incorporated into a larger one, $76 \mathrm{~m}$ long, by adding and interpolating stratigraphic data recorded from 9 boreholes that was drilled in a straight line and cutting the paleochannel perpendicularly (Fig. 5). This two-scaled approach to the site's natural stratigraphy was very useful when posing questions related to site formation and environment. The profile of the trench will be described first and then the stratigraphy of the whole paleochannel will be presented.

In the trench, topsoil made up of ploughed peat and gyttja was $0.4 \mathrm{~m}$ thick. Gyttja sediments were usually immediately followed below topsoil. Highly

decomposed unploughed peat overlying gyttja survived only fragmentarily (Fig. 6). A gyttja layer was $0.3 \mathrm{~m}$ thick in the northwestern end of the trench and $2 \mathrm{~m}$ thick in the southeastern end of the trench. Plant detritus (e.g. Trapa natans fruits, tree leaves and twigs) was common in the middle and lower part of the gyttja, while the uppermost part was dry, cracked and contained no plant remains (Fig. 6). The lower part of the gyttja was much sandier and contained small lenses of fine, sometimes coarse or even gravelly 

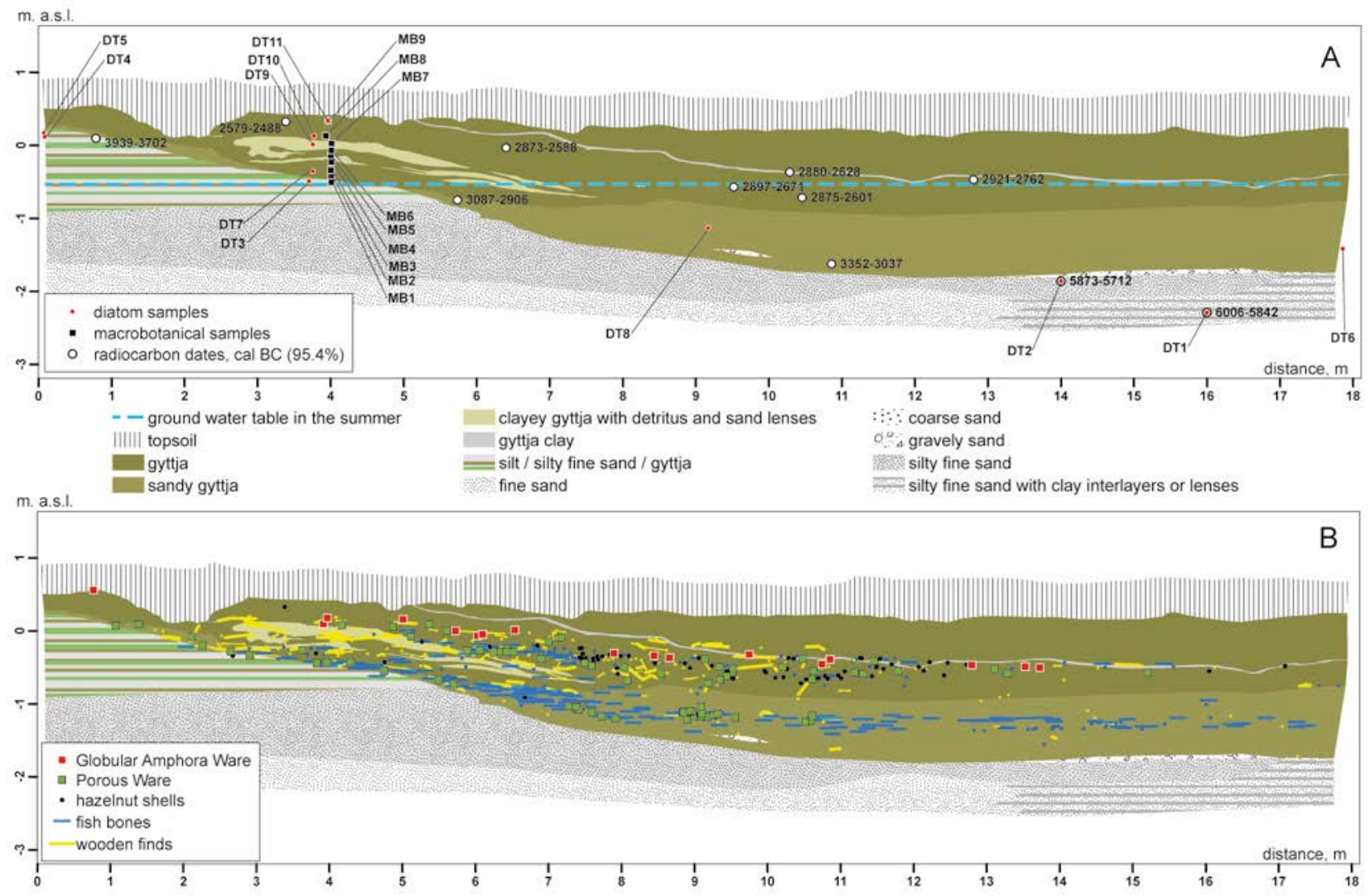

Fig. 4. Natural (A) and cultural (B) stratigraphy in the 2014 trench at Šventoji 2/4. Soil samples for macro-botanical (MB1-9) and diatom (DT1-11) analyses are indicated. ${ }^{14} \mathrm{C}$ dated terrestrial samples are indicated by calibrated ages with a $95 \%$ probability ranges. Drawing by G. Piličiauskas.

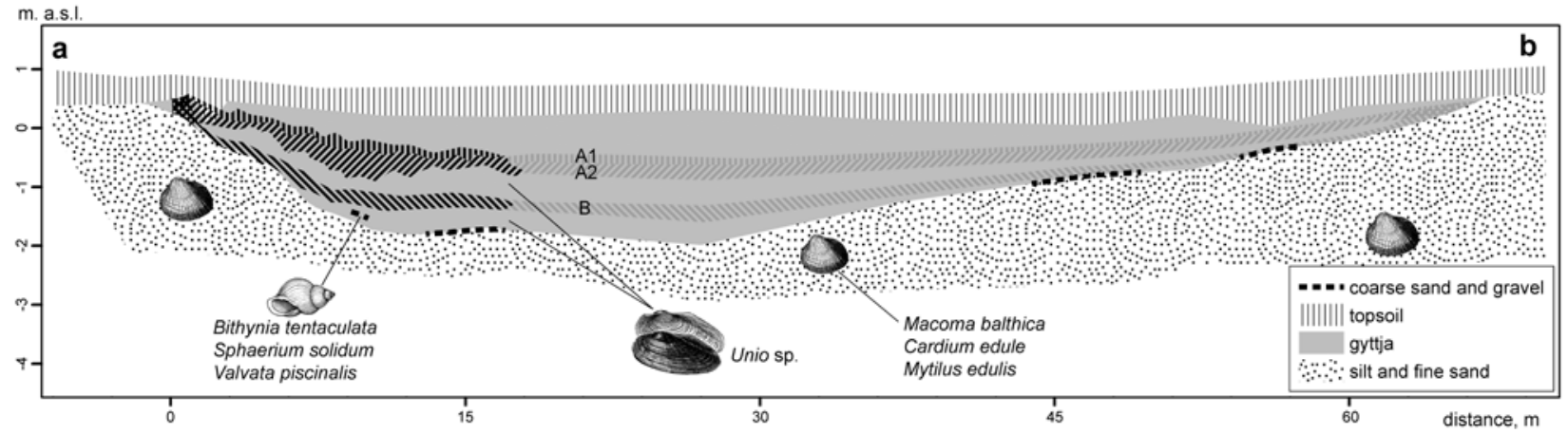

Fig. 5. Section of paleochannel exaggerated by a factor of 3 and with mollusc species and archaeological layers (A1, A2 and B) indicated. Drawing by G. Piličiauskas. 


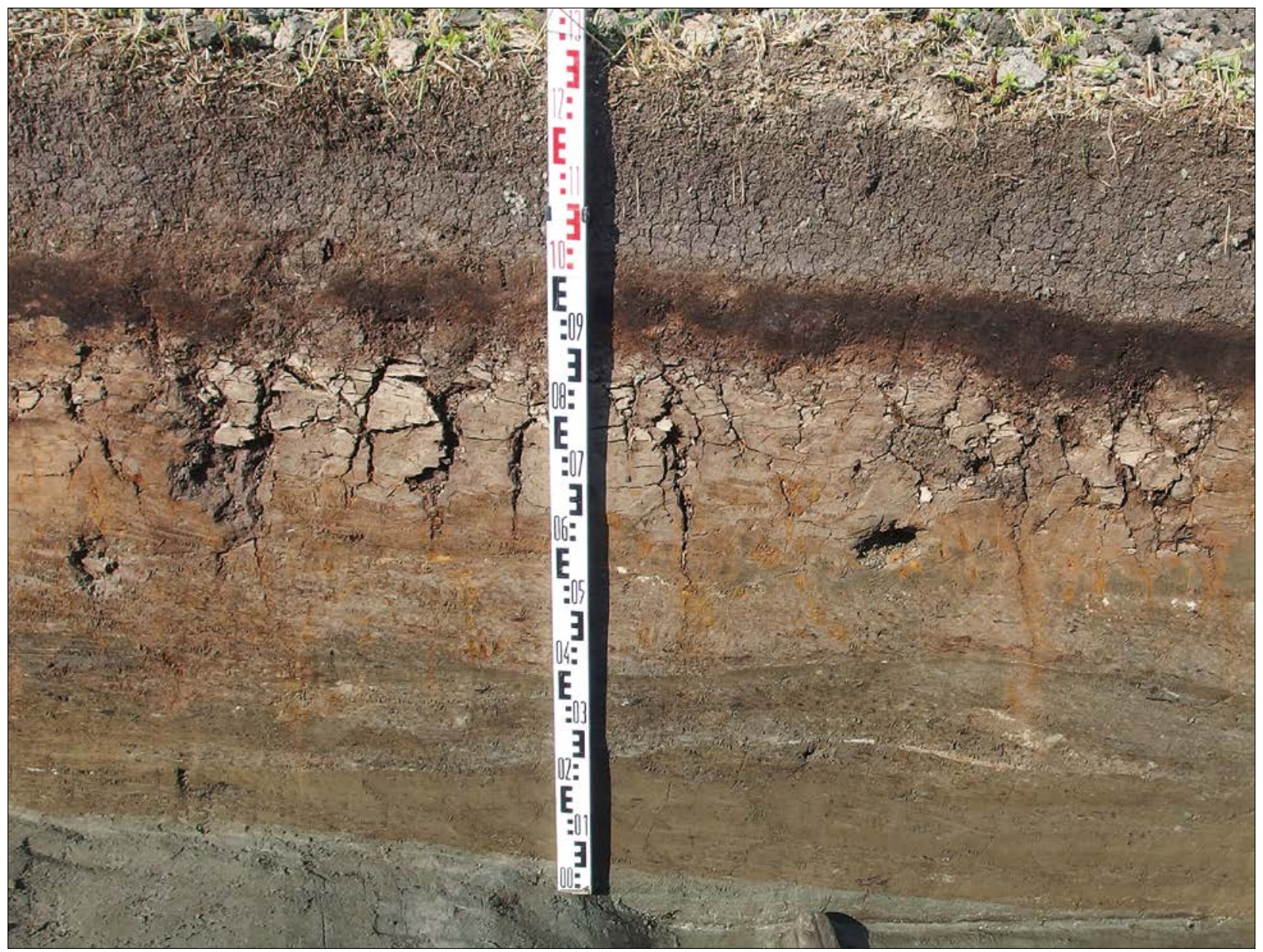

Fig. 6. Example of stratigraphy in the northwestern slope of the paleochannel. Šventoji 2/4, trench of 2014. Photo by G. Piličiauskas.

sand. On the slope of the ancient paleochannel, where artefact density was highest, gyttja was of lighter colour and more clayey (Fig. 4 and 6). Gyttja was underlain by laminated silt/fine sand/gyttja sediments that have been completely washed out in the deepest parts of the paleochannel. Deeper lying silty sand also contained organic inclusions, mainly consisting of plant remains. The same or very similar stratigraphies of the northwestern slope of the paleochannel were recorded during previous excavations of Šventoji 2/4, although in less detail (Juodagalvis, Simpson 2000; Rimantienè 2005; Brazaitis 2007).

Drilling in the other parts of paleochannel showed that the whole bed is filled with gyttja.
However, the southeastern slope of paleochannel has a slightly different topography to that of the northwestern slope, the former being shallower and less steep. Lenses or thin interlayers of gravelly sand were also documented in the very bottom of the paleochannel outside the trench (Fig. 5).

\section{PH AND PRESERVATION OF ORGANIC REMAINS}

Acidity/alkalinity or $\mathrm{pH}$ of the archaeological layer (gyttja), underlying lagoonal sediments (silt) and ground water was measured by using an Adwa AD $111 \mathrm{pH}$-ORP meter combined with an A1230B electrode (Table 1). 


\begin{tabular}{|c|c|c|l|c|}
\hline No & depth, $\mathbf{m}$ & m a.s.l. & \multicolumn{1}{|c|}{ description } & pH \\
\hline 1 & 0.68 & 0.13 & $\begin{array}{l}\text { gyttja brown, cracked due } \\
\text { to drying }\end{array}$ & 4.2 \\
\hline 2 & 0.80 & 0.01 & clayey gyttja & 4.3 \\
\hline 3 & 1.17 & -0.36 & sandy gyttja & 5.7 \\
\hline 4 & 1.30 & -0.49 & $\begin{array}{l}\text { silt below archaeological } \\
\text { layer }\end{array}$ & 6.6 \\
\hline 5 & 0.97 & -0.33 & ground water & 5.6 \\
\hline
\end{tabular}

Table 1. $\mathrm{pH}$ values of the archaeological layer (gyttja), lagoonal sediments (silt) and ground water at Šventoji $2 / 4$.

The upper part of archaeological layer (samples No 1 and 2 in Table 1) with pH values of 4.2 and 4.3 demonstrates an acidic environment. The bottom part of the gyttja (sample No. 3 in Table 1) with a pH value of 5.7 is less acidic, although it is still too acidic to preserve mollusc shells. Only thin coatings of Unio sp. shells were documented during the excavation of the middle and lower parts of the gyttja (Fig. 5). However, in general, modest acidity in the layer did not prevent the preservation of bones and wooden objects, which were found in great numbers in 2014 as well as during previous excavations. As could be expected, wood was much better preserved in the lower part of the archaeological layer, lying beneath the water table rather than above it.

\section{MOLLUSCS}

Fossil molluscs were collected directly during excavation or picked out from borehole cores and sediment samples. In the laboratory, fossil molluscs were selected by sieving, using a mesh diameter of up to $1 \mathrm{~mm}$, or by exposing the sediment to a $10 \%$ sodium pyrophosphate $(\mathrm{Na} 5 \mathrm{P} 3 \mathrm{O} 10)$ solution for the isolation of water insoluble mollusc shells and valves. Fossil molluscs were identified using the naked eye and a binocular microscope. The identification reliability was verified by comparing fossil molluscs with the collection of Baltic Sea molluscs (Kessel 1958) and using malacofauna atlases
(Šivickis 1960; Glöer, Meier-Brook 1998; Tavast 2000; Gurskas 2010).

At various depths of the gyttja, starting from the very bottom, thin coatings of Unio sp. shells, most likely of Unio tumidus, were observed. Their main bodies were completely dissolved due to humic acids. Unio tumidus prefers sandy and muddy bottoms of lakes, oxbows, and slowly running rivers (Šivickis 1960). From the bottom part of gyttja, which contained much sand, as well as from the lenses of sand within gyttja, shells of Bithynia tentaculata, Sphaerium solidum, and Valvata piscinalis were recovered (Fig. 5). Today Bithynia tentaculata inhabits freshwater ponds, lakes, and channels (Šivickis 1960). Sphaerium solidum lives on sandy bottoms of rivers and lakes (Gurskas 2010). Valvata piscinalis prefer muddy bottoms of standing or slowly running freshwater water bodies (Gurskas 2010).

Silty and sandy sediments lying below gyttja contained fragments of 3 marine mollusc species: Macoma balthica, Cardium edule, and Mytilus edulis. All of these taxa inhabit the rocky offshore of the tidal zone. These mollusc communities are characteristic of shallow (up to 5-10 $\mathrm{m}$ in depth) littoral zones with sandy or silty (fossil valves of $M$. baltica) or sometimes rocky (fossil Mytilus edulis) bottoms in the areas containing boulders, gravel, or pebbles (M. baltica and M. edulis community) (Kessel 1958; Oleninas et al. 1996). They were typical for the Littorina Sea ecosystem (Damušytė 2011).

\section{DIATOMS}

Eleven soil samples, each $2 \mathrm{~cm}$ thick and $20 \mathrm{ml}$ in volume, were taken from the trench wall and from borehole cores for diatom analysis (Fig. 4A). Sediment samples were prepared in laboratory following the techniques described in Battarbee (1986). Diatom species were identified under 'Nikon Eclipse 200' microscope (magnification $\mathrm{x} 1000$ ). Identification of taxa was based mainly on Krammer \& Lange-Bertalot 
(1986-1991), also using Snoeijs (1993), Snoeijs, Vilbaste (1994), Snoeijs, Potapova (1995), Snoeijs, Kasperovičienè (1996), and Snoeijs, Balashova (1998). Ecological requirements of diatom taxa are described mainly using the checklists of Van Dam et al. (1994) and Barinova et al. (2006). Ecological groups were divided according to salinity (Van Dam et al. 1994): fresh $-<0.2 \%$; fresh-brackish $-<0.9 \%$; brackish-fresh - \%00.9-1.8; brackish - 1.8-9.0\%o. For the calculation and presentation of the diatom data, the program TILIA (Grimm 2011) was applied. Taxa occurring in a relative abundance of $>1 \%$ in the sediment samples are presented in the diatom diagram. Names of diatom taxa were checked and updated using taxonomic nomenclature in the AlgaeBase database.

Two samples (DT1 and DT2) from the lowermost layer, made up of silty fine sand, did not contain any diatoms. Sample DT3 was taken from laminated sandy and silty sediments, which included more organics when compared with samples DT1 and DT2. In DT3 taxa characteristic for marine environments (benthic Odontella ?aurita, Grammatophora marina, Hyalodiscus scoticus and planktonic Actinocyclus octonarius), which were common for Littorina Sea littoral zone, made up $45 \%$ of the sample's composition (Fig. 7). Samples DT4 and DT5 were taken from the upper part of the same laminated sandy and silty sediments, immediately below gyttja (Fig. 4A). The amount of fresh-brackish diatoms (e.g. Aulacoseira granulata, Epithemia adnata, E. turgida, Amphora ovalis, Pinnularia viridis, Gyrosigma attenuatum) increases in both samples compared to DT3, although brackish diatoms (e.g. Diploneis smithii var. rhombica and Campylodiscus clypeus) are still present (Fig. 7). Sediments were deposited

Fig. 7. Diagrams showing the results of diatom analysis at Šventoji 2/4. Samples are listed chronologically, with the oldest at the bottom and the youngest at the top, and according to the stratigraphy (see Fig. 4A). Compiled by G. Vaikutiene.

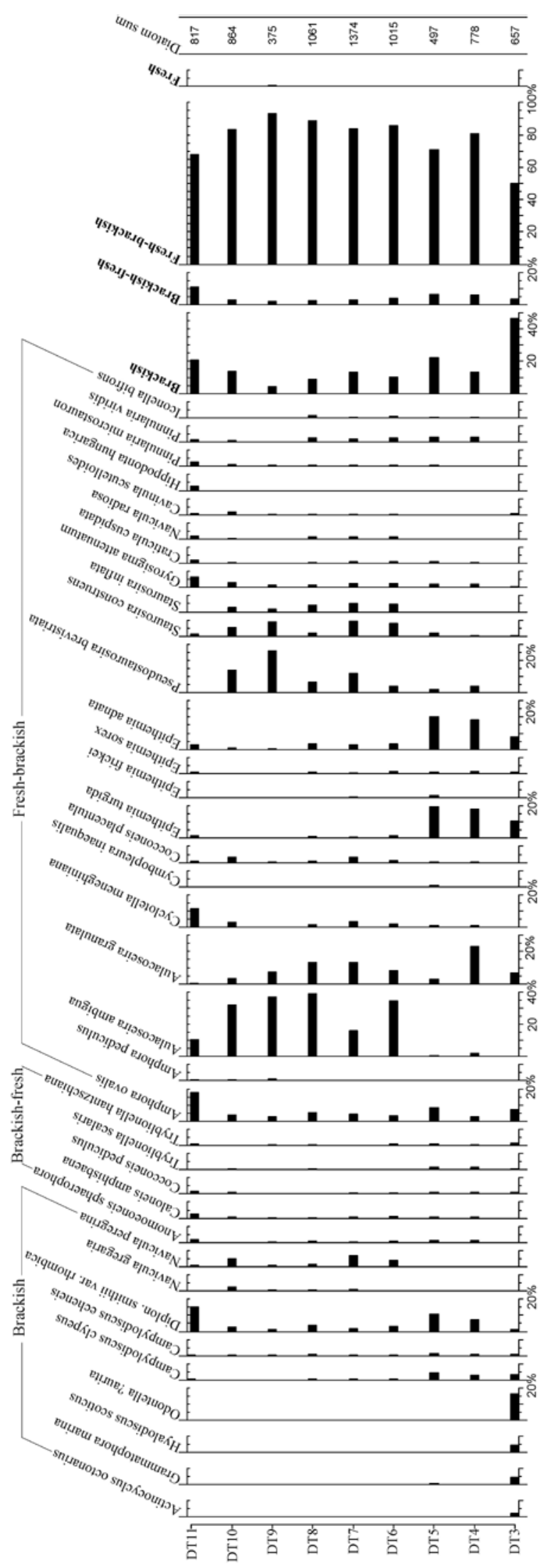


in shallow freshwater environment probably under the influence of permanent, but minor intrusions of brackish water. The structure of the diatom assemblage changes considerably in gyttja samples DT6-DT10 with significant increase in freshbrackish planktonic (e.g. Aulacoseira ambigua and A. granulata) and benthic (e.g. Pseudostaurosira brevistriata and Staurosira construens) diatoms (Fig. 7). From these results we can glean that the environment became almost freshwater with insignificant inflows of brackish water. In the topmost sample, DT11, there was an increased amount of benthic brackish diatoms (mainly Diploneis smithii var. rhombica) and a slightly decreased percentage of planktonic fresh-brackish taxa that can be observed. Such changes in the diatom composition indicate a fall of the water level in the basin and negligible intrusions of brackish water.

\section{PLANT MACROREMAINS}

Nine soil samples, $5 \mathrm{~cm}$ thick each, were taken for macro-botanical analysis from a single column in the trench wall in 2014 (Fig. 4A). The analysis was performed at the Laboratory of Quaternary Research at Nature Research Centre in Vilnius. The organic macro-remains were extracted from subsamples of 2 litres each by wet sieving through a screen with a mesh size of $200 \mu \mathrm{m}$. The dried material was sorted using a stereomicroscope with 10-120 x magnification, and plant macrofossils were identified using atlases of Grigas (1986), Cappers et al. (2006), Berggren (1969; 1981), and the reference collection of modern plants. Plant remains belonging to 48 plant taxa were identified. Results of macro-botanical analysis are presented in table 2 and figure 8.

Sample MB1 was taken from laminated sandy and silty sediments below the archaeological layer
(Fig. 4A). Remains of Ruppia maritima, Zannichelia palustris and Chara sp. dominated in this sample (Table 2). These aquatic plants together with Salicornia europaea belong to the group of halophytic plants characterizing a brackish water environment. Most of the aquatic plant taxa identified in MB1 prefer the depth of $0.4-1.5 \mathrm{~m}$, though they could have tolerated deeper waters. Finds of Menyanthes trifoliata, which thrives in shallow, low-nutrient pools, peat bogs and marshes, attests sediment formation in the shallow zone of the body of water or in close proximity to it.

The composition of plant macro-remain assemblages identified in the gyttja samples MB2MB9 greatly differs from that of MB1. Halophytes disappear from the palaeoflora, while freshwater taxa prevail. In gyttja, Nymphaea alba, accompanied by Najas marina and Potamogeton perfoliatus, dominates among aquatic plants, while the number of wetland and terrestrial plants increases considerably (Fig. 8). Water chestnut (Trapa natans) fruits were not identified in the gyttja samples (Table 2), but were found in great numbers during the excavations, starting from the bottom of gyttja sediments up to its dry and cracked upper layer (Fig. 6). Most of them were waterlogged and uncharred and therefore should be considered as natural ecofacts that sunk in the lake in their natural habitat or nearbyit. Today Trapa natans is extinct in Lithuania, but still grows in the modern-day neighbouring country of Belarus and in several lakes in Eastern Latvia (Ванкина 1970). In the temperate zone, Trapa natans prefers to grow at the depth of 0.5-2.5 meters in nutrient-rich, shallow, and warm bodies of water with muddy bottoms and standing or sluggish water. ${ }^{3}$

In samples MB2-MB9, Typha latifolia, Schoenoplectus lacustris, Alisma plantago-aquatica, Scirpus sylvaticus, Ranunculus sceleratus were

\footnotetext{
${ }^{3}$ A very detailed overview with many references cited of Trapa natans in its modern and prehistoric habitats and its distribution across Eastern Europe has been provided by Ahlqvist (2007).
} 


\begin{tabular}{|c|c|c|c|c|c|c|c|c|c|}
\hline \multirow{3}{*}{ Plant species } & \multicolumn{9}{|c|}{ Sample depth/code } \\
\hline & 1.35 & 1.25 & 1.18 & 1.07 & 0.98 & 0.91 & 0.82 & 0.71 & 0.5 \\
\hline & MB1 & MB2 & MB3 & MB4 & MB5 & MB6 & MB7 & MB8 & MB9 \\
\hline Chara sp. & 27 & 1 & & 1 & & & & & \\
\hline Ruppia maritima & 38 & & & & & & & & \\
\hline Zannichelia palustris & 30 & 1 & & & & & & & \\
\hline Najas marina & 3 & 2 & & 6 & 2 & & & & \\
\hline Nymphaeae alba & 1 & 10 & 7 & 6 & 7 & 10 & 10 & & \\
\hline Nuphar lutea & & & 1 & & 2 & & & & \\
\hline Potamogeton praelongus & & & & & & & 2 & & \\
\hline Potamogeton pectinatus & 1 & & & & & & & & \\
\hline Potamogeton perfoliatus & & 1 & 2 & 2 & & 1 & 2 & & \\
\hline Potamogeton natans & & & & & & 1 & & & \\
\hline Potamogeton sp. & & & & & & & 1 & & \\
\hline Batrachium sp. & & 1 & & & & & & & \\
\hline Alisma plantago-aquatica & & 3 & 1 & 1 & 5 & & & & \\
\hline Lycopus europaeus & & & 1 & 7 & 2 & 1 & & & \\
\hline Persicaria hydropiper & & & & 18 & 23 & 4 & 5 & & \\
\hline Typha latifolia & & 18 & 2 & 2 & 32 & 5 & & & \\
\hline Sparganium emersum & & 1 & & & & & & & \\
\hline Scirpus sylvaticus & 1 & 2 & & & & & & & \\
\hline Schoenoplectus tabernamontani & & & & 1 & & & & & \\
\hline Schoenoplectus lacustris & & 10 & 20 & 15 & 14 & 12 & 4 & & \\
\hline Eleocharis palustris & & & & & & 1 & & & \\
\hline Carexpseudocyperus & & 2 & & & & & 1 & & \\
\hline Carex hirta & & & & 2 & 6 & & 2 & & \\
\hline Carex sp. & 2 & & & & 2 & 3 & & & \\
\hline Ranunculus repens & & & & & 1 & & & & \\
\hline Ranunculus sceleratus & 1 & 2 & 2 & 1 & & & & & \\
\hline Sphagnum sp. & 2 & & & & & & & & \\
\hline Menyanthes trifoliata & 10 & 3 & & & 2 & & 1 & & \\
\hline Valeriana officinalis & 1 & & & & & & & & \\
\hline Solanum dulcamara & & 2 & 2 & & & & & & \\
\hline Salicornia europaea & 2 & & & & & & & & \\
\hline Myosoton aquaticum & & & & & 4 & & & & \\
\hline Persicaria lapathifolia & & 17 & 4 & 30 & 25 & 6 & 2 & 3 & \\
\hline Urtica dioica & & 106 & 52 & 60 & 186 & 53 & 90 & 2 & \\
\hline Filipendula ulmaria & 1 & & & & & & & & \\
\hline Chenopodium murale & & 6 & 1 & & & & & & \\
\hline Chenopodium alba & & 6 & & & & & & & \\
\hline Chenopodium sp. & & & & & 1 & & & & \\
\hline Asteraceae & 1 & & & & & & & & \\
\hline Galeopsis bifida/ tetrahit & & & & & 2 & & & & \\
\hline Galeopsis pubescens & & & & 6 & & & & & \\
\hline Rumex acetosella & & & & 1 & & & & & \\
\hline Atriplex prostrata & & & & 6 & 5 & 4 & 5 & & \\
\hline Fallopia convolvulus & & & & & 5 & 3 & & & \\
\hline Stellaria media & & & & & & 1 & & & \\
\hline Stellaria uliginosa & & & & & & 1 & & & \\
\hline Humulus lupulus & & & & & & 2 & & & \\
\hline
\end{tabular}

Table 2. Results of macro-botanical analysis at Šventoji 2/4.

For the sampling locations see Fig. 4A. 


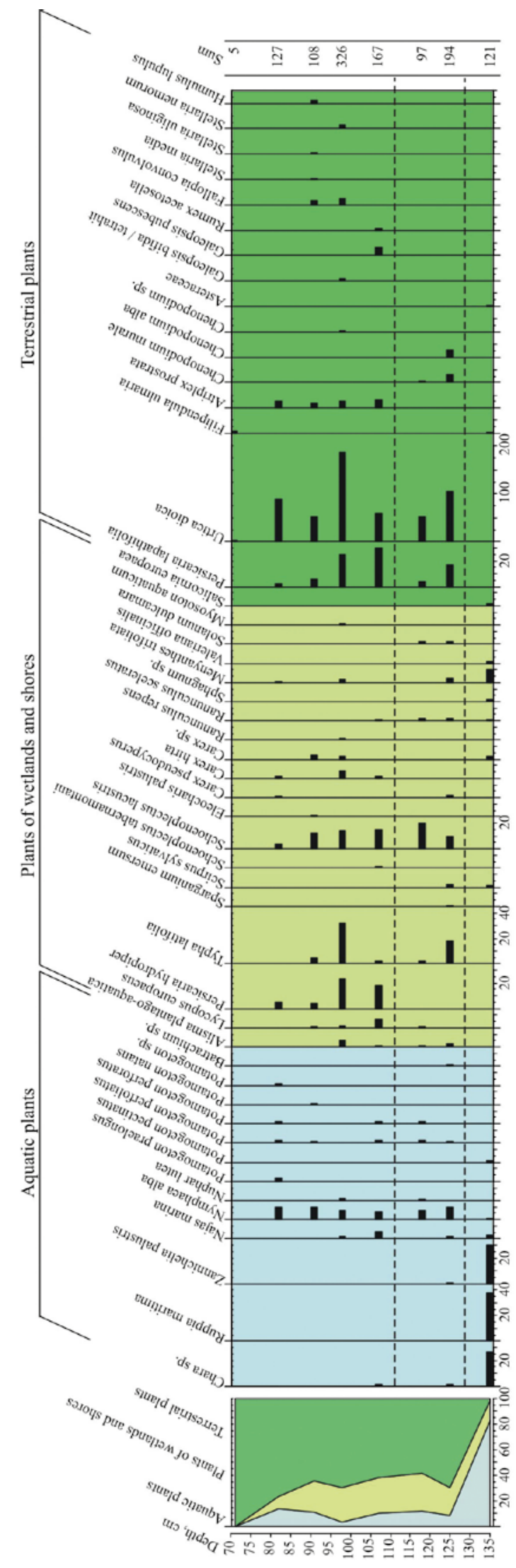

identified among wetland and shore plants. Nowadays these taxa are found in flooded environments with standing or slowly running water. On the drier banks of the former lake or inflowing rivers, Urtica dioica, Persicaria lapathifolia, and Chenopodium sp. were common. In sample MB4 Galeopsis pubescens, Atriplex prostrata, and Rumex acetosella occur. These plants are common as the initial vegetation of eroded soils and perhaps may be related with onshore human activities. Samples MB8 and MB9 were taken from the upper part of the gyttja where organics were badly preserved due to overdrying of the lacustrine sediments. Therefore, MB8 contained only very few plant remains, while MB9 had none at all (Table 2).

\section{CULTURAL STRATIGRAPHY}

No archaeological finds were found in the sandy and silty deposits below the gyttja at Šventoji $2 / 4$. Most of them were recovered from the gyttja, while very few were found in the ploughed topsoil. In the latter, tiny potsherds of Porous Ware were found, which were uplifted from the deeper-lying gyttja during the excavation of the drainage ditches in 1966-1967 and later were fragmented and dispersed by ploughing.

Not all parts of the gyttja contained artefacts and their density was very different depending on the depth and distance to the slope of the paleochannel. Ceramic potsherds, regardless of their type, were mostly concentrated in the northwestern slope of the paleochannel (Fig. 4B). However, we know from the 2006 and 2015 excavations that they were also present in the middle part and on the opposite slope of the paleochannel, although in smaller numbers (Brazaitis 2007; Kurilienè et al. 2016). The whole paleochannel

Fig. 8. Diagram showing sums of identified plant taxa per sample at Šventoji 2/4, which were grouped into 3 classes according to the habitat type. Compiled by D. Kisieliene. 
was filled with human waste, although the density of it is higher on slope areas and particularly on the northwestern slope (Fig 5).

Two archaeological layers, characterized by a greater density of archaeological finds may be distinguished within the gyttja (Fig. 4B and 5). The lower one was referred to as layer $B$, while the upper one was referred to as A by Rimantiené (2005). In general, we will follow that designation. The lower archaeological layer B was about 0.2-0.3 meters thick and culturally homogenous. It contained only organic-tempered Porous Ware pottery (Fig. 9B), including an almost intact large pointed-base vessel (Fig. 10). Layer B does not begin from the bottom of the gyttja, however. The oldest gyttja, up to $0.5 \mathrm{~m}$ thick, contained very few wooden artefacts and fish bones and no pottery. A distinct archaeological layer (B) with many artefacts and a high concentration of fish bones began just above it (Fig. 11). In layer $\mathrm{B}$, fish bones were often found densely packed into lenses of sandy gyttja. Among them burnt bones and charcoal were present, which indicates an anthropogenic origin of these remains. This was also confirmed by the unnatural composition of the fish bone assemblage (see chapter on bones).

The upper archaeological layer (A) was $0.3-0.5 \mathrm{~m}$ thick and separated from the lower lying layer $B$ by about $0.5 \mathrm{~m}$ thick gyttja without pottery, but still containing some wooden artefacts and fish bones, which were probably eroded from the horizon of $B$ and redeposited in between $\mathrm{B}$ and $\mathrm{A}$ (Fig. 4B). It is also important to note that in the slope zone many fragments of burnt reed were noted in the gyttja in between layers $\mathrm{A}$ and $\mathrm{B}$. Layer $\mathrm{A}$, however, is not homogenous culturally. It contains potsherds of Porous (Fig. 9:A2) and Globular Amphora (Fig. 12) wares. The latter were always found above the former (Fig. 4B). This allows the archaeological layer A to be divided into Neolithic (A1) and Subneolithic (A2) horizons (Fig. 5). Unfortunately, pottery fragments of both types were too scarce to draw a precise boundary between the Neolithic and Subneolithic horizons. From the limited data, it seems that the youngest Subneolithic horizon (A2) is about 0.2 meters thick, while the Neolithic one (A1) is only several centimetres thick.

Two four $\mathrm{cm}$ thick interlayer of lighter-coloured clayey gyttja marks the end of the deposition of human waste. Only a few wooden artefacts and sporadic fish bones were found above this interlayer and these appear to have been eroded following their deposition.

As aforementioned, in other parts of the paleochannel the same natural stratigraphy was documented during previous excavations (Juodagalvis, Simpson 2000; Rimantienè 2005; Brazaitis 2007). The same, however, cannot be said about archaeological stratigraphy. All archaeologists who excavated at Šventoji $2 / 4$ noted that artefacts are distributed in two distinct layers separated by sterile gyttja. However, R. Rimantienè and V. Juodagalvis claimed that all artefacts from the upper layer (A) belonged exclusively to the Globular Amphora culture (hereinafter GAC), while all Porous Ware potsherds were found only in the lower layer (B) (Juodagalvis, Simpson 2000; Rimantienè 2005). A short paper on excavations in 2006 does not include information about archaeological stratigraphy, unfortunately (Brazaitis 2007). However, the data from the excavations in 2014 contradicts Rimantienès and Juodagalvis's position and proves that layer $\mathrm{A}$ contains both Subneolithic and Neolithic pottery. The results of excavations in the southeastern part of the paleochannel in 2015 are important in this regard since the results correspond to the data from the excavation in 2014, with two types of pottery recorded in layer A (Kurilienè et al. 2016). In order to verify cultural stratigraphy in older trenches, we plotted organic-tempered Subneolithic and mineraltempered Neolithic pottery fragments from the 2003 trench excavated by V. Juodagalvis into a single profile. This profile again shows that 2 types of 


\begin{tabular}{|c|c|c|c|c|c|c|c|c|c|c|c|c|c|}
\hline \multirow{2}{*}{$\begin{array}{c}\text { archaeological } \\
\text { layer }\end{array}$} & \multicolumn{2}{|c|}{ pottery } & \multicolumn{2}{|c|}{$\begin{array}{c}\text { worked } \\
\text { amber }\end{array}$} & \multicolumn{2}{|c|}{ flint } & \multicolumn{2}{|c|}{ other rocks } & \multicolumn{3}{|c|}{ wood } & \multirow{2}{*}{$\begin{array}{l}\text { hazelnut } \\
\text { shells }\end{array}$} & \multirow{2}{*}{$\begin{array}{c}\text { burnt } \\
\text { water } \\
\text { chestnuts }\end{array}$} \\
\hline & $\mathbf{n}$ & g & $\mathbf{n}$ & $\mathrm{g}$ & $\mathbf{n}$ & g & $\mathbf{n}$ & g & laths & chips & other & & \\
\hline A1 & 17 & 458 & & & & & 14 & 2853 & \multirow{3}{*}{81} & \multirow{3}{*}{71} & \multirow{3}{*}{71} & 2 & \\
\hline A2 & 43 & 746 & 2 & 0.2 & 1 & 10.1 & 12 & 1616 & & & & 62 & 21 \\
\hline B & 33 & $513^{*}$ & 1 & 0.6 & & & 6 & 182 & & & & 4 & 2 \\
\hline ploughed zone & 26 & 14 & 2 & 3.5 & & & 2 & 7 & & & & & \\
\hline sum & 119 & $1731^{\star}$ & 5 & 4.3 & 1 & 10.1 & 34 & 4658 & & 223 & & 68 & 23 \\
\hline
\end{tabular}

Table 3. Numbers of archaeological finds including hazelnut shells and burnt water chestnuts found in 2014 trench at Šventoji 2/4 according archaeological stratigraphy. ${ }^{*}$-weight of the almost intact Porous Ware vessel was not included.

pottery are present in the upper archaeological layer A (Fig. 13). It should be noted that the 2003 trench was situated $200 \mathrm{~m}$ from the 2014 trench, although it has been excavated on the same northwestern slope of the paleochannel (Fig. 2). The 2003 trench profile provides a hint as to why Rimantiene and Juodagalvis described the cultural stratigraphy differently than our and Kurilienè et al.'s study (2016). It seems that in previously excavated trenches that GAC pottery clearly dominates in layer A (Fig. 13), while in the 2014 trench Porous Ware was more numerous (Fig. 4B). Perhaps the amount of Porous Ware potsherds in layer A was too low for previous researchers to be confident about the presence of Subneolithic materials in layer A.

\section{ARTEFACTS}

In the 2014 trench 223 wooden and 123 ceramic finds were recovered. Various wooden artefacts from small chips to poles with sharpened ends were found at various depths, including the intermediate space between layers A and B (Fig. 4B); therefore their attribution to particular archaeological layer was complicated in many cases. Furthermore, floatability of the wooden objects should be taken into account, as it may lead to a considerable time gap between the discard of a wooden artefact and its eventual burial in the muddy sediment of the lake or river bottom. The distribution of artefacts of various types according to archaeological horizons is provided in Table 3.

In total, only 118 potsherds and 1 almost intact vessel were found in the $36 \mathrm{~m}^{2}$ size trench during the 2014 excavation at Šventoji 2/4. The pottery density in all archaeological layers therefore could be described as low and uncharacteristic of a dwelling zone. In layer B, 36 potsherds and 1 vessel were found. Vessels were shell-tempered and undecorated and had pointed bases and straight rims with round or flattened edges (Fig. 9:B). Pottery from horizon A2 was also tempered with shell mostly, although in combination with small amounts of mineral temper in some cases. Bases were pointed like in layer B, but rims were of different shapes: straight, with edges slanted inward (Fig. 9:A2). Vessels' upper parts and edges were ornamented with knot/plait impressions (Fig. 9:A2). Pottery from layer B and horizon A2 should be attributed to Porous Ware, which was produced by the last hunters-gatherers in the Southeastern Baltic.

Neolithic pottery from horizon A1 differs greatly from the Subneolithic pottery of horizon A 2 and layer $B$ in all aspects. It was tempered with coarse crushed stone (2-4 $\mathrm{mm}$ size grains), and is flat-bottomed, has S-profile walls, cord ornamentation, knobs and lugs attached (Fig. 12). Amphorae and vase-like vessels have been recovered. Pottery from horizon 

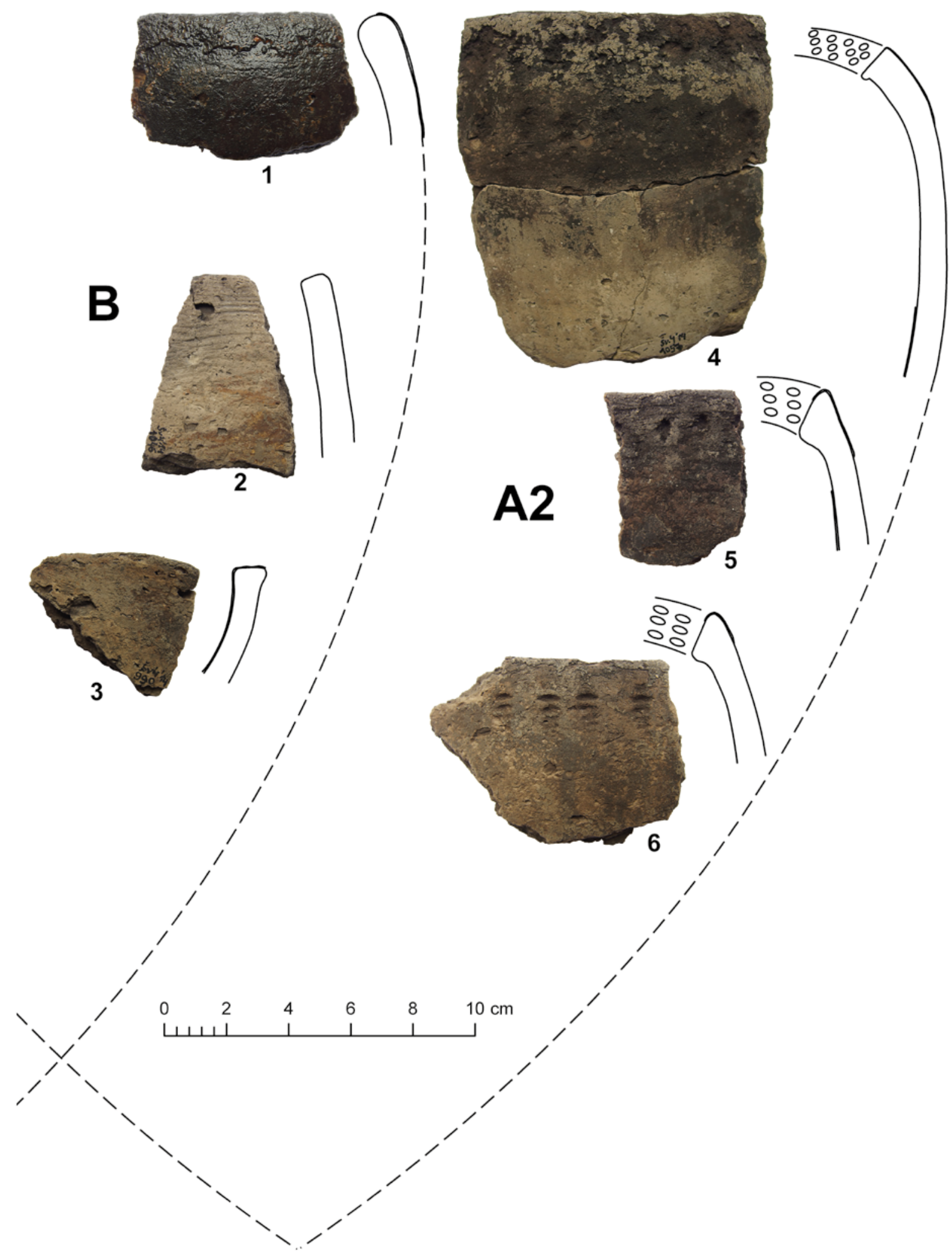

Fig. 9. Porous Ware potsherds from layers B and A2 at Šventoji 2/4. Drawing and photo by G. Piličiauskas. 


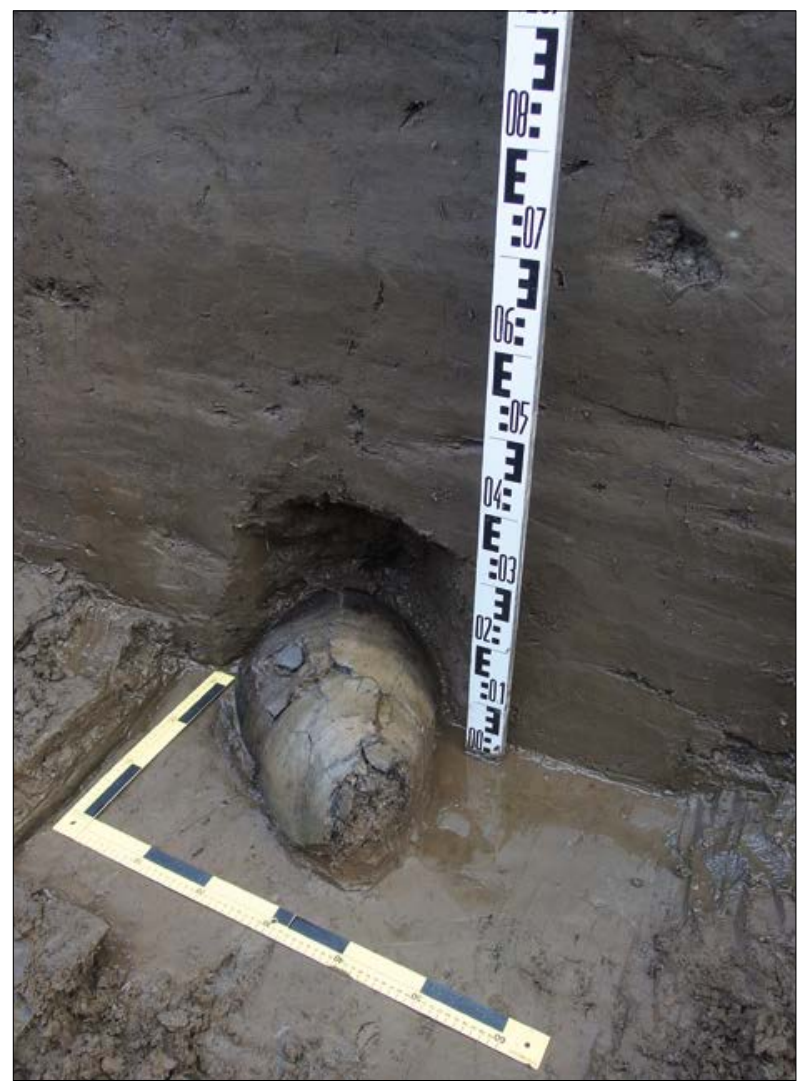

Fig. 10. Porous Ware vessel with the pointed base broken off, found in layer B of Šventoji 2/4 in 2014. Photo by G. Piličiauskas.

A1 should be attributed to Globular Amphora Ware, which is one of the first Neolithic pottery types in the Southeastern Baltic.

In all three archaeological layers/horizons some potsherds had plant materials adhering to their flat surfaces and even along the breaks (Fig. 14:1-2). It seems that potsherds were wrapped with tree bast thread and may have been used as light-weighted net sinkers instead of ending up as simple kitchen waste. This also raises the question whether all potsherds with drilled holes (e.g. Fig. 14:3) are from repaired vessels indeed? Perhaps some holes were drilled with an intention to reuse pottery fragments as net sinkers.

Only 5 worked amber pieces, 4 flakes and 1 preform, were found. They were present in layers A2 and $\mathrm{B}$ as well as in the ploughed zone. The only flint

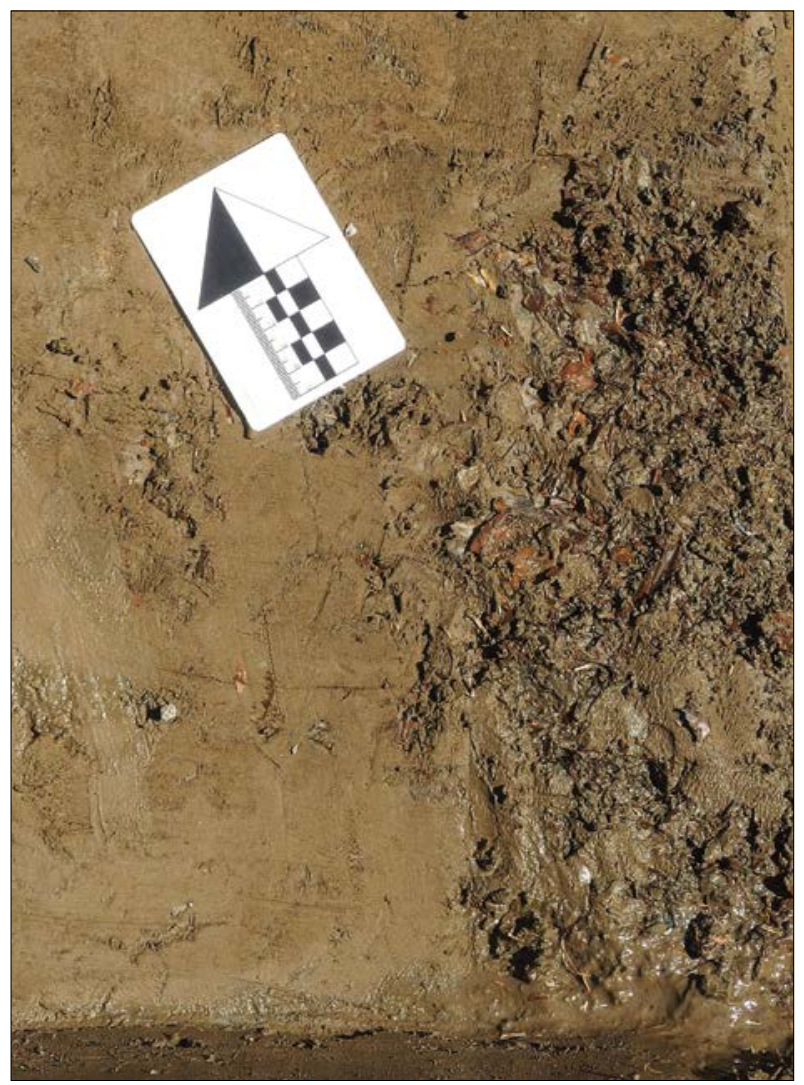

Fig. 11. Accumulation of freshwater fish bones uncovered in layer B of Šventoji 2/4. Photo by G. Piličiauskas.

artefact was a bipolar core $4 \mathrm{~cm}$ long that was found in horizon A2. Among 34 other rock specimens, 26 were unworked beach pebbles, usually $3-10 \mathrm{~cm}$ in size, 3 were net sinkers made of flat notched sandstone pebbles, and 5 were flakes and crumbles. Most of the unworked pebbles could also have served as net sinkers, since during previous excavations at Šventoji 2/4 and at other Šventoji sites similar specimens were sometimes found tied with wood bast or wrapped in birch bark (Rimantienè 2005).

Because all 3 archaeological layers/horizons were waterlogged, wooden tools and processing waste composed the largest category of finds at Šventoji $2 / 4$. However, they were highly fragmented and sometimes parts of them that protruded outside the trench were not recovered. Therefore, the original size, form, and function of wooden objects was only 

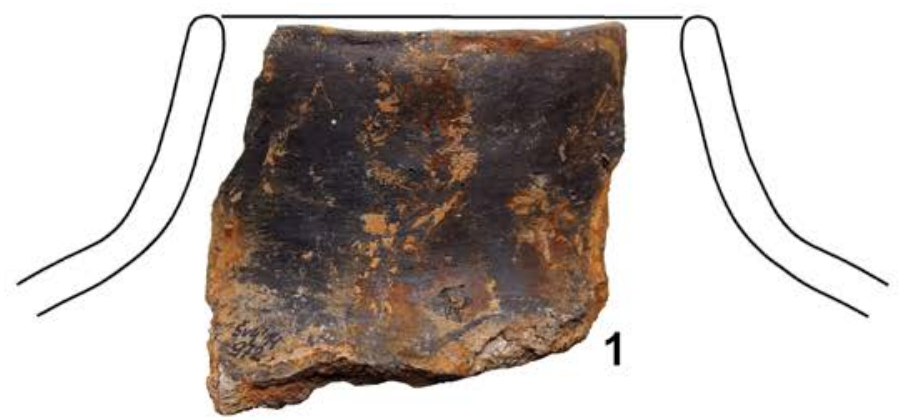

A1
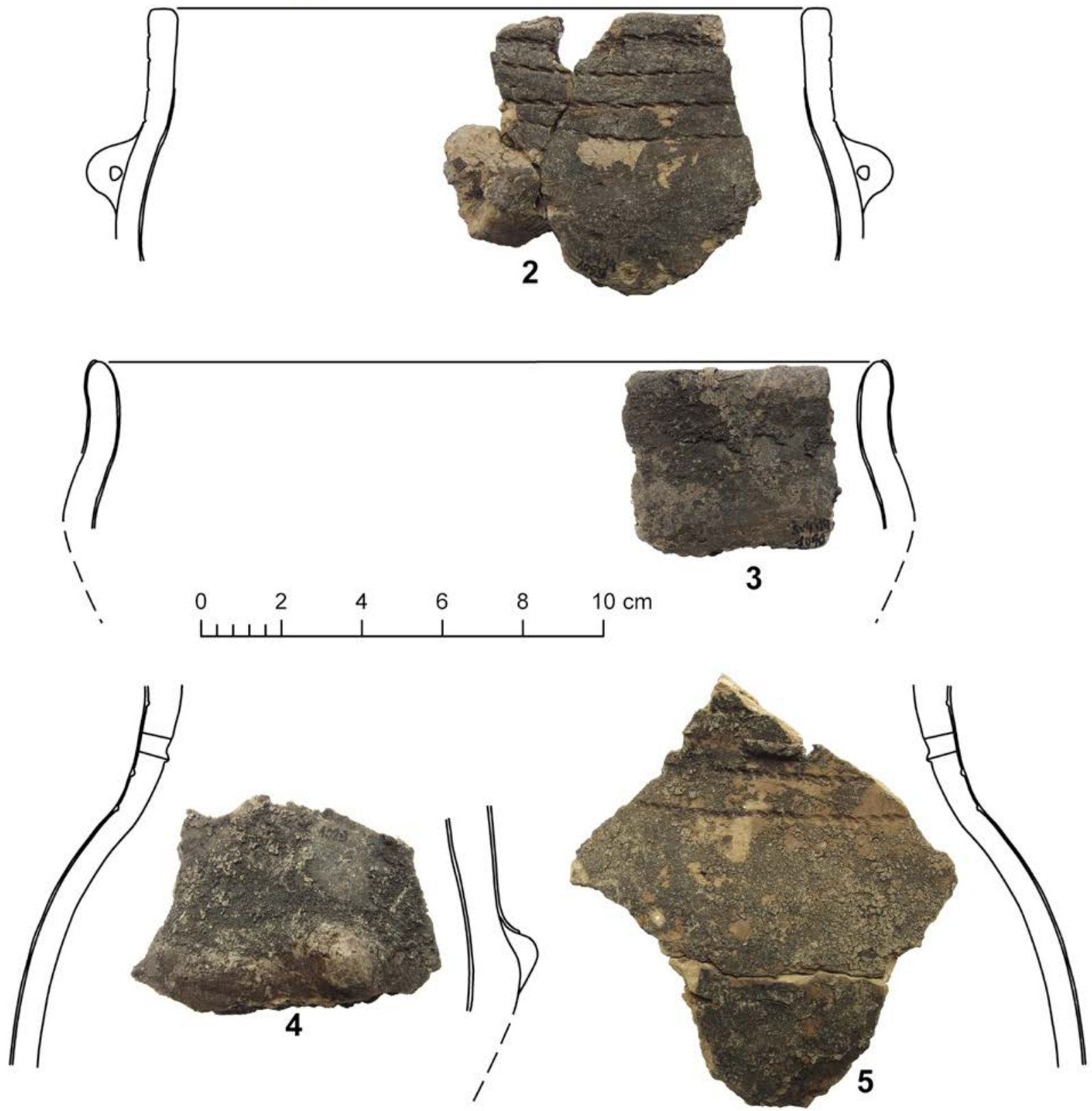

Fig. 12. GAC potsherds from layer A1 at Šventoji 2/4 in 2014. Drawing and photo by G. Piličiauskas. 


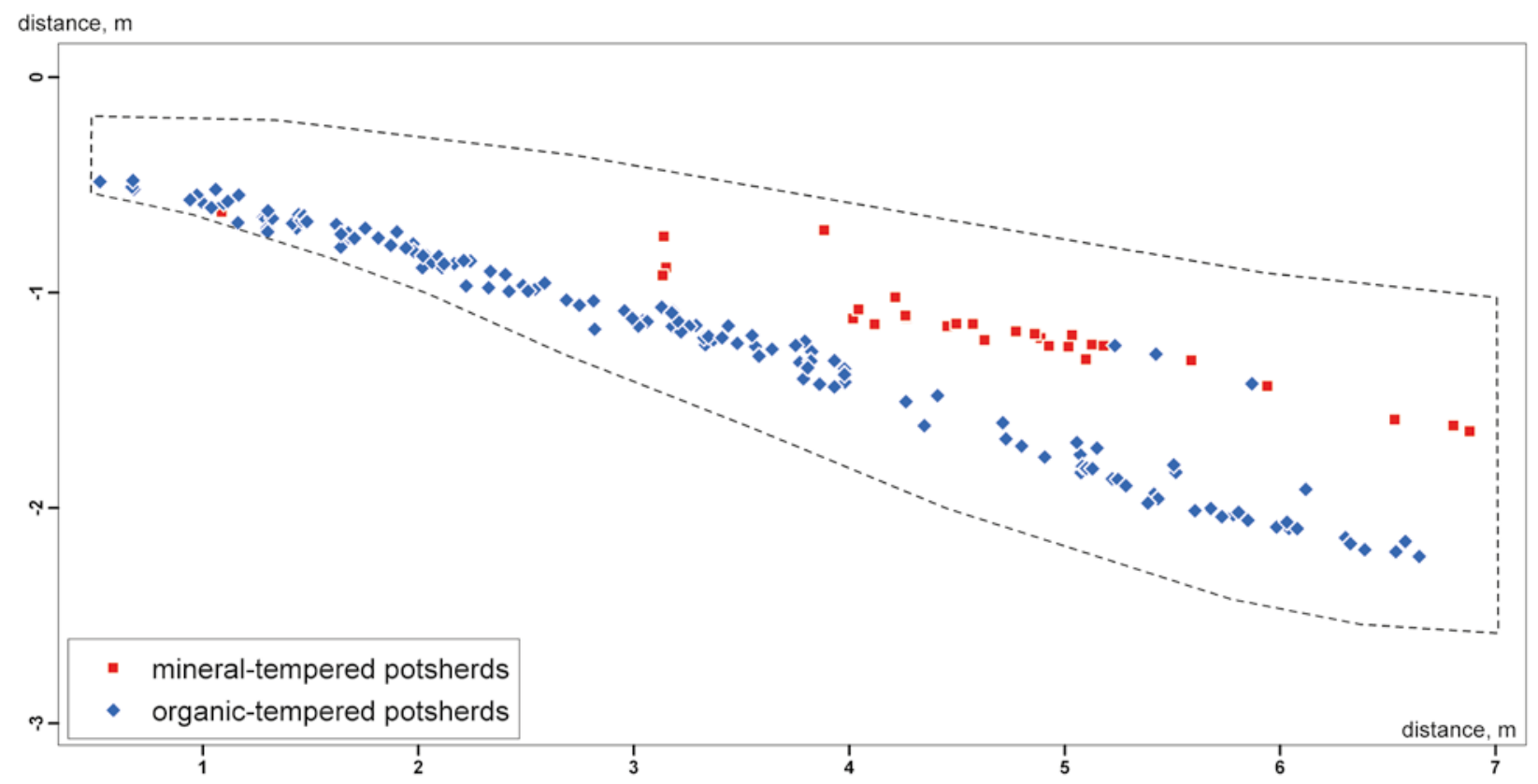

Fig. 13. Cultural stratigraphy in the 2003 excavations at Šventoji 2/4. Note the two types of pottery present in the upper archaeological layer. Drawing by L. Gaižauskas.

rarely clear. Wood taxa were identified by analysing thin sections under Optica B-193 bright-field microscope, between 40 and 1000x magnification. The identification of wood anatomical features was based on Wheeler (2011) and Schoch et al. (2004).

Fragments of pine laths were most numerous among wooden finds (Table 3). These fragments usually were only a few $\mathrm{cm}$ long, although the largest was $0.8 \mathrm{~m}$ in length. However, from other Subneolithic sites in the Šventoji area and in the East Baltic we know that they could reach $2 \mathrm{~m}$ long and were used as the main material for the construction of stationary fishing gear, such as fences and traps (Lozovski 1999; Rimantienè 2005; Bērziņš 2008; Koivisto 2012). A small fragment of a fishing basket or screen found in 2014 (Fig. 15) proves that sometimes laths were attached to wooden frame with lime (?) bast threads. Pine laths were found in layers B and A2 in large numbers and were certainly widely used during the Subneolithic in Šventoji. Whether they were used in the Neolithic is a complicated question. Several lath fragments were found in the same depth or even above GAC potsherds, but these few finds may be outwashed from older sediments and redeposited. In 2015, a fish fence or screen was uncovered at Šventoji 58. The screen was dated to 2619-2462 cal $\mathrm{BC}$ and was ascribed to the Corded Ware culture. It is interesting to note that this find was not made of pine laths, but of hazel twigs bound together with lime bast (Piličiauskas et al. in prep.). Therefore, it seems that Corded Ware fishermen did not use pine laths on the Lithuania coast.

Wood chips were numerous in all layers. They were most likely discarded while mounting and repairing stationary fishing gear. Chips were cut from alder, elm, willow, ash and hazel tree trunks and branches. Hazel and ash were mostly used for thin sticks of unknown function, only $2-3 \mathrm{~cm}$ in diameter, sometimes with one end sharpened. In all archaeological layers, bark fragments of unidentified wood taxa up to $0.6 \mathrm{~m}$ in size were present. They were absent in other parts of the gyttja and therefore were most likely discarded by humans. Some bark fragments have visible cut marks (Fig. 16). 

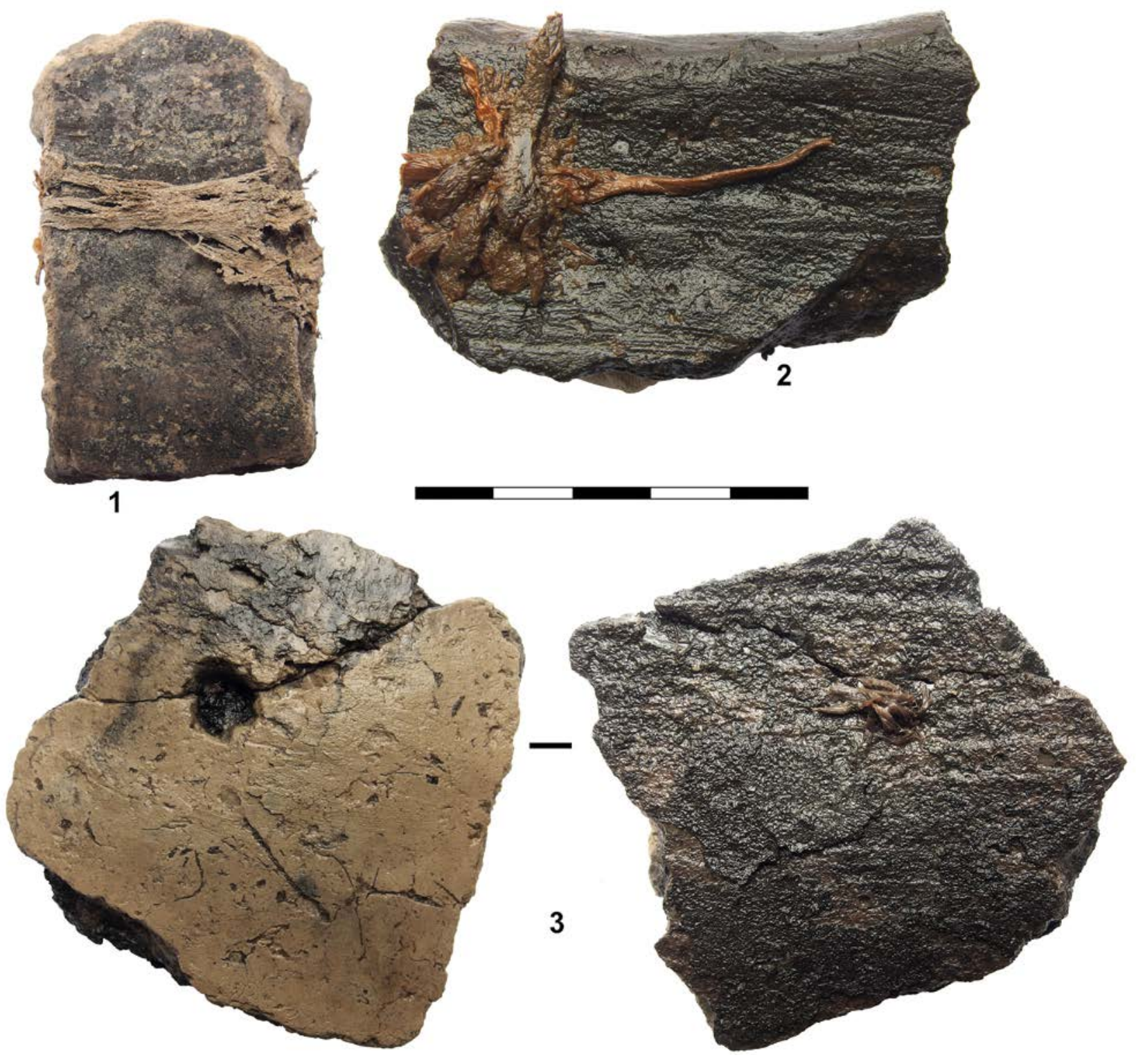

Fig. 14. Porous Ware potsherds from the 2014 trench at Šventoji $2 / 4$ with plant materials adhering to the surface or preserved inside the drilled holes, which may have been used as very light net sinkers. Photo by G. Piličiauskas.

Rimantiene (2005) wrote that in the area of about $2000 \mathrm{~m}^{2}$ excavated at Šventoji $2 / 4$, only 66 poles were uncovered and all were less than $6 \mathrm{~cm}$ in diameter. In 2014, only 2 fragments of horizontally lying poles with sharpened ends were found. They were recovered from layers B and A2 and were made from young willow and hazel trunks respectively. Both were only
3-4 cm thick. In layer A2, a third pole of unidentified wood was uncovered and was still standing in vertical position. It was only $0.47 \mathrm{~m}$ long and had both ends sharpened.

A badly preserved wooden hoe $1.3 \mathrm{~m}$ long was found in horizon A2. It was made from a branch of an ash tree by rounding and flattening the stem 


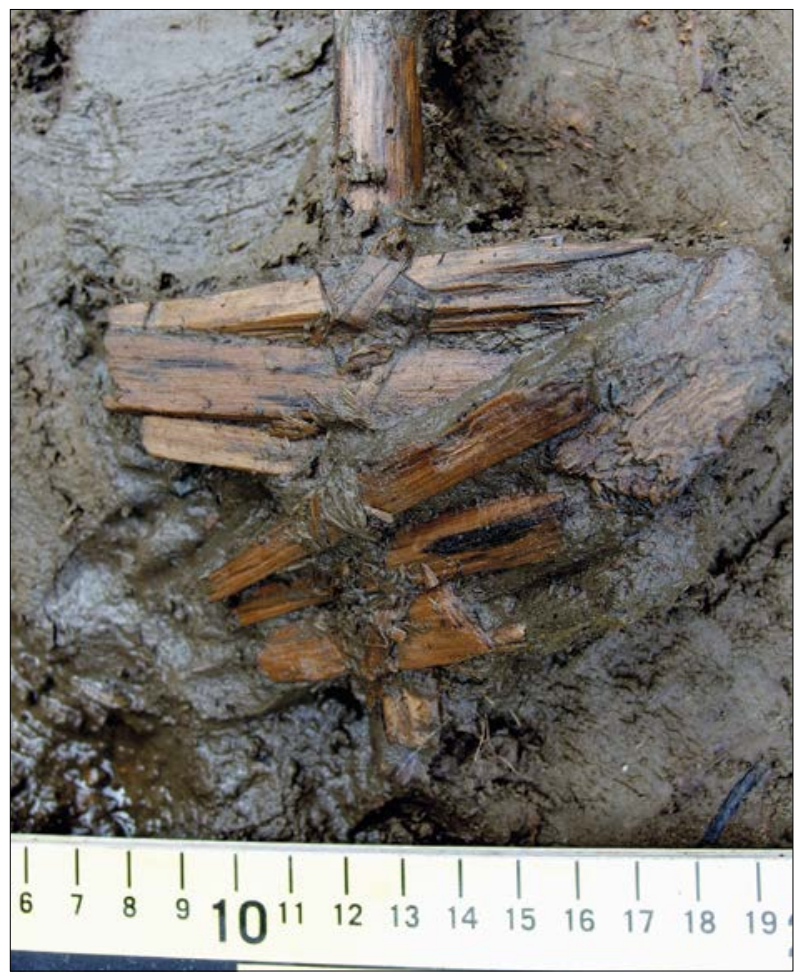

Fig. 15. Fragment of fish screen or basket made of pine laths attached with lime (?) bast binding to a hazel frame. Šventoji 2/4, layer A2. Photo by G. Piličiauskas.

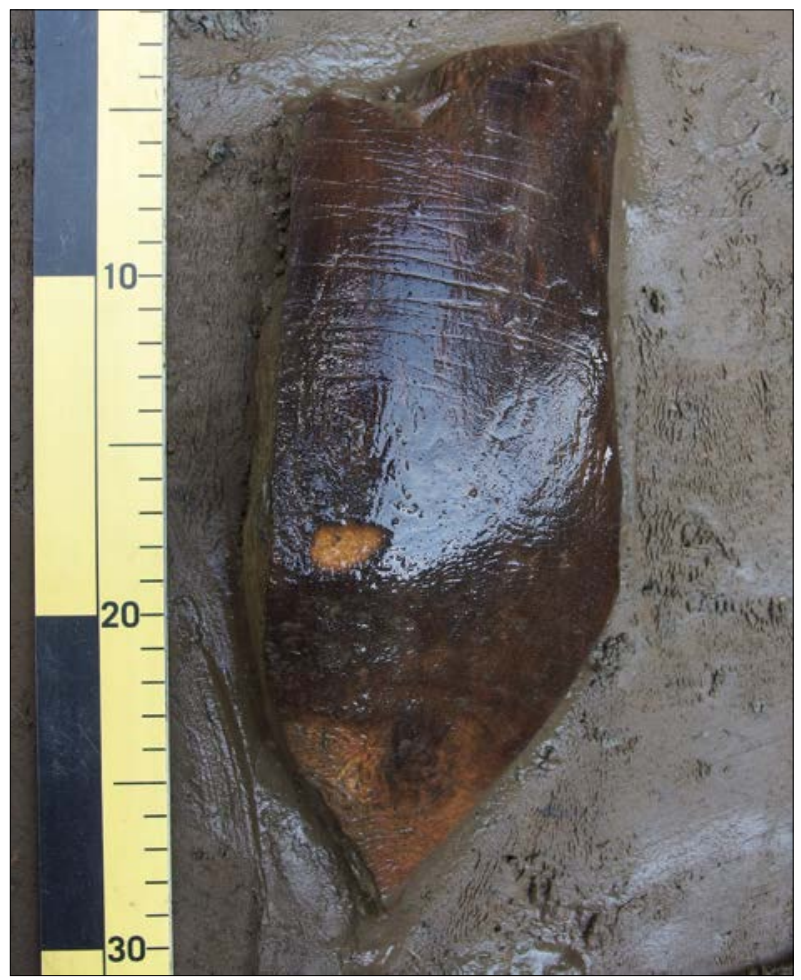

Fig. 17. Fragment of a trough made of ash wood in layer B of Šventoji 2/4. Photo by G. Piličiauskas.

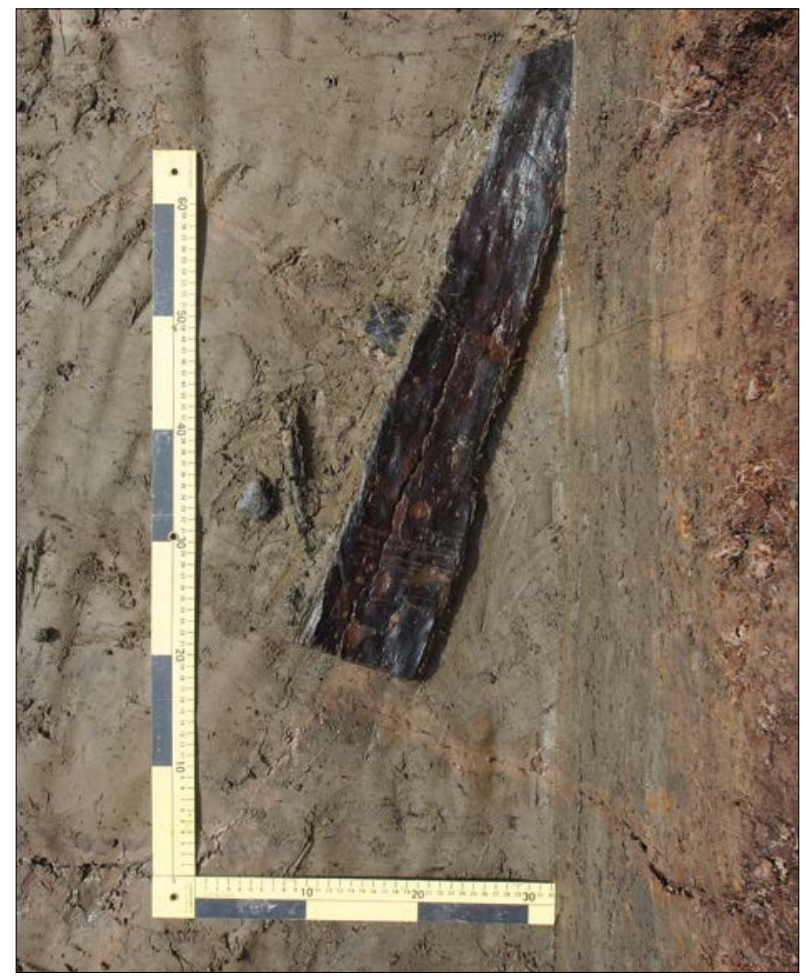

Fig. 16. Bark of unidentified tree with incisions on the inside surface that was found in layer A1 of Šventoji 2/4 site. Photo by G. Piličiauskas.

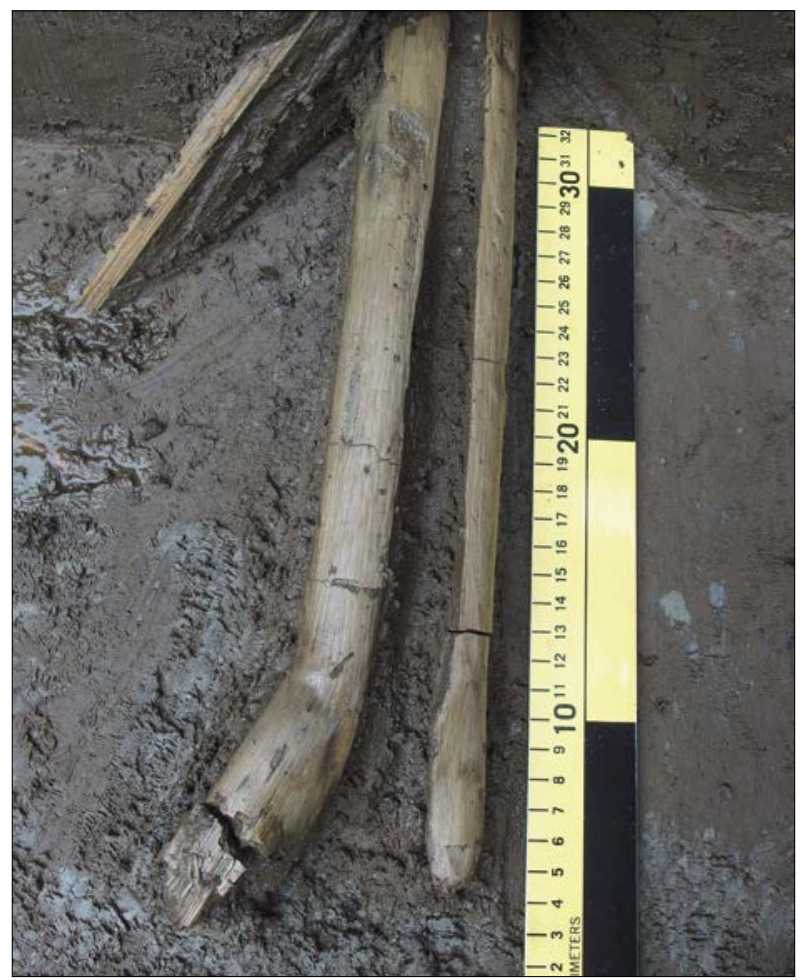

Fig. 18. Leister prongs made of ash wood that was found in horizon A2 of Šventoji 2/4. Photo by G. Piličiauskas. 
part. Such tools are known at other Subneolithic sites in the East Baltic - Šventoji 1, 3, 6 and 23, Sārnate and Zvidze (Ванкина 1970; Лозе 1988; Rimantienè 2005). However, it is still not clear whether these tools were used to cultivate plants or to collect wild resources (Piličiauskas et al. 2017a). A fragment of a trough made of ash wood was uncovered from layer B (Fig. 17). The fishing spear is another wooden tool type well known from previous excavations in Šventoji. Two leister prongs made of ash wood were found together in horizon A2 (Fig. 18). Charcoal or partly charred wood fragments were extremely rare in the trench. 9 were found in total and 6 of them, mostly of alder tree, in horizon A2. It is interesting to note that waterlogged hazelnut shells and charred water chestnuts have also been found mostly in A2 horizon (Fig. 4B; Table 3). Such distributional pattern implies that they were more likely human waste rather than natural remains.

If we would compare these finds with those that have been recovered during previous excavation campaigns at Šventoji 2/4, it is clear that they are not different, although the latter are much more diverse in types, forms, and functions because of the larger area that was excavated. For instance, they include wooden axe sockets and handles, scoops, mauls, paddles, bows and logboat fragments, digging sticks, birch bark and lime bast vessels, birch bark floats, bone net needles, scrapers, awls and harpoons, animal teeth pendants, non-shaft-hole stone axes, lime (?) bast net fragments, and even wooden pole with a carved human head in its upper end (Rimantienè 2005). During previous excavations a much larger pottery assemblage compared to that of 2014 trench was collected. However, in many cases it is not clear in which archaeological layer or horizon a particular potsherd was found.

\section{FAUNAL REMAINS}

\section{Mammals and birds}

More than 20,000 bone and teeth fragments were collected at Šventoji 2/4 in 2014. From these only 17 were of mammals and birds (Table 4). Ten bones found in layer B were identified as seal, common vole, roe deer, unidentified ungulates, and unidentified birds. Five bones from horizon A2 were identified as to seal, elk, and unidentified birds. However, no mammalian or bird bones were found in horizon A1. Seal bones from all layers consisted of vertebrae and ribs, which could not be identified to the level of species. All 4 bird bone fragments were from long bones, and therefore the determination of their species was also not possible.

\begin{tabular}{|c|l|c|}
\hline $\begin{array}{c}\text { Cultural layer/ } \\
\text { horizon }\end{array}$ & \multicolumn{1}{|c|}{ Species/family } & $\begin{array}{c}\text { Number } \\
\text { of bones }\end{array}$ \\
\hline \multirow{4}{*}{ A2 } & Phocidae & 3 \\
\cline { 2 - 3 } & Alces alces & 1 \\
\cline { 2 - 3 } & unidentified birds & 2 \\
\hline \multirow{4}{*}{ B } & Phocidae & 3 \\
\cline { 2 - 3 } & Microtus arvalis & 3 \\
\cline { 2 - 3 } & Capreolus capreolus & 1 \\
\cline { 2 - 3 } & unidentified ungulates & 2 \\
\cline { 2 - 3 } & unidentified birds & 17 \\
\hline Total number & & \\
\hline
\end{tabular}

Table 4. Mammal and bird bone numbers according cultural layers/horizons found at Šventoji 2/4 in 2014.

From the assemblage recovered in earlier excavations, 450 mammal and bird bones were identified (Stančikaite et al. 2009). Among them seal bones $(n=238)$ dominated, but bird bones, mostly of water fowl, were also numerous $(n=108)$. Forest game was represented by boar (Sus scrofa; $\mathrm{n}=46$ ), beaver (Castor fiber; $\mathrm{n}=30$ ), red deer (Cervus elaphus; $\mathrm{n}=21$ ), aurochs (Bos primigenius; $\mathrm{n}=19$ ), and elk (Alces alces; $\mathrm{n}=18$ ). The same tendency, where the zooarchaeological material is dominated by seal, is 
also evident in the contemporaneous dwelling sites of Šventoji 23 and 26. Zooarchaeological data from Šventoji 2/4 site shows that the Subneolithic-Neolithic ${ }^{4}$ fishermen's diet in time of fishing expeditions was not restricted to fish. They also ate seals, forest game, and water fowl.

\section{Fish}

Fish bones clearly dominated the faunal assemblage of Šventoji 2/4. However, their distribution according to cultural layers/horizons is extremely uneven. From more than 20,000 fish bone fragments only 14 were found in horizon A1, 311 in A2, and all others were found in layer B (Table 5).

\begin{tabular}{|c|c|c|}
\hline Layer/horizon & Number of bones & Identified \\
\hline A1 & 14 & 4 \\
\hline A2 & 311 & 49 \\
\hline B & ca. 20,000 & 4109 \\
\hline
\end{tabular}

Table 5. Number of fish bones according cultural layers/horizons found at Šventoji 2/4 in 2014.

Fish bone identifications were carried out using the comparative reference collection. Quantification of the fish remains was based on a count of the total number of identified specimens (NISP) of each taxon. The size of the fish was determined by the fish of a known length in a reference collection.

From 14 fish bones assigned to the Neolithic horizon A1, 4 were identified as cyprinids and 1 as pike. However, due to unclear boundary between horizons A1 and A2, all or a fraction of these 14 bones may belong to the Subneolithic horizon A2.

More fish bones $(n=311)$ were recovered from the Subneolithic horizon A2. From these 49 (15.8 \%) were identified to the level of species or family. Among them cranial and fin bones $(67.7 \%)$ outnumbered spinal bones (33.3\%). However, all fish bones in horizon A2 were handpicked and cranial bones are easier to spot than vertebrae during excavation. This may have a direct impact on their larger presence in the assemblage. All fish bones belong to freshwater species: pike (34.7\%), zander (24.5\%), and cyprinids (34.4\%) (Fig. 19). This corroborates diatom and macro-botanical data and attests the mainly freshwater character of Šventoji lagoonal lake during the Neolithic. However, the number of identified bones was too low for a reliable reconstruction of dominant lengths of various fish taxa from layer A2.

In the assemblage of around 20,000 fish bone fragments found in layer B, cranial and fin bones (72.3\%) vastly outnumbered spinal bones (27.7 \%), as was already observed in horizon A2. Burnt bones of large and medium size individuals comprised $0.3 \%$ in the assemblage. The composition of the assemblage and the small amount of burnt bones, together with close spatial associations between fish bones, pottery and other human waste, confirms that the deposition of fish bones at Šventoji $2 / 4$ is of an anthropogenic nature rather than due to natural causes as it once was proposed (Stančikaitè et al. 2009). Most of recovered vertebrae belong to small cyprinids and perch, while the vertebrae of larger fish were usually the ones closest to cranial part of the skeleton. 4,109 have been identified to the level of species or family. At least 16 fish taxa were attested. The majority of bones (98.5\%) belong to at least 10 freshwater fish taxa. Cyprinids (82.2\%) were most numerous (Fig. 20). A large part of their bones were not identified to the level of species, although it is likely that most of them belong to bream (Abramis brama). Bream bones (24.6\%) were most common among cyprinid bones identified to the level of species. Other cyprinid species, such as common rudd (Scardinius erythrophthalmus; $0.6 \%$ ), tench (Tinca tinca; $0.6 \%$ ), and roach (Rutilus rutilus; $0.3 \%$ ) were much less numerous. Among predatory fish,

\footnotetext{
${ }^{4}$ Numbers of bones from older excavations were sometimes not ascribed to different horizons.
} 


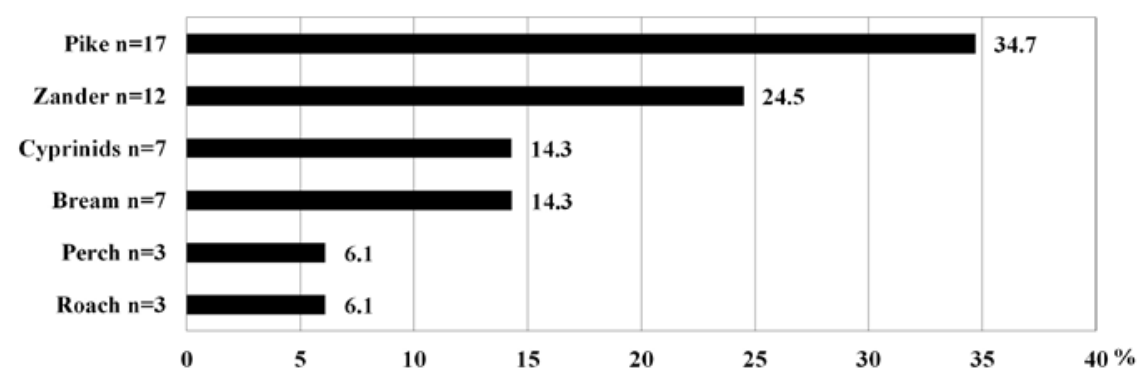

Fig. 19. Fish bone species from layer A2 of Šventoji 2/4. Compiled by G. Piličiauskiené.

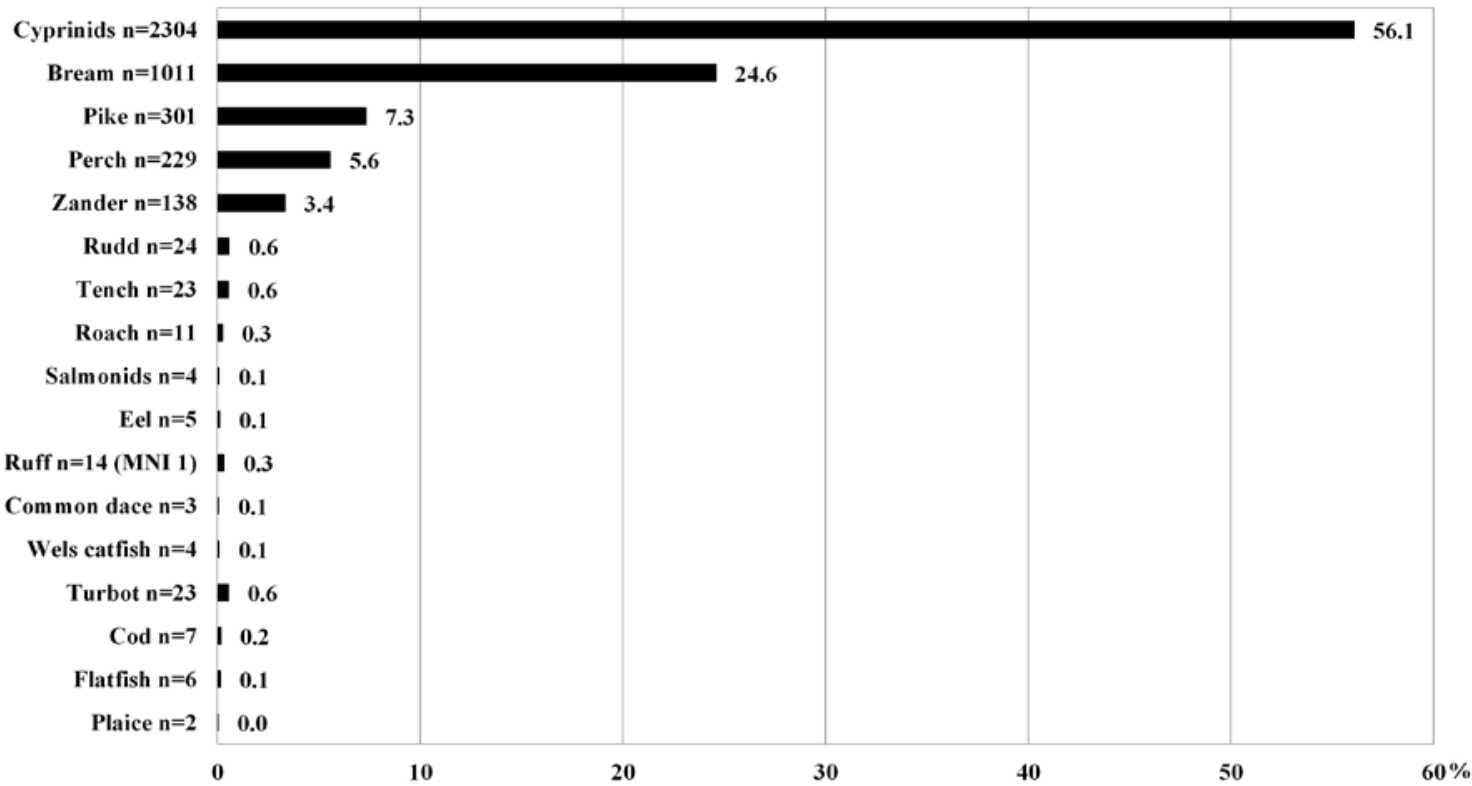

Fig. 20. Fish bone taxa from layer B of Šventoji 2/4. Compiled by G. Piličiauskienè.

pike (Esox lucius; $7.3 \%$ ), perch (Perca fluviatilis; $5.6 \%$ ), and zander (Sander lucioperca; $3.4 \%$ ) were identified. Marine species, such as European plaice (Pleuronectes platessa), Atlantic cod (Gadus morhua) and turbot (Scophthalmus maximus) accounted for only $0.9 \%$ of the whole fish bone assemblage and bones of migratory fish, such as salmonids and eel (Anguilla anguilla) were even more scarce (Fig. 20). The length of cyprinids varied from $5-10 \mathrm{~cm}$ to $45-$ $50 \mathrm{~cm}$. Most breams that were caught were $30-45 \mathrm{~cm}$ long and tench were $30-35 \mathrm{~cm}$ long. However, rudd and roach were much smaller. Among pike and zander individuals that were $30-80 \mathrm{~cm}$ long prevailed, while perch was represented by individuals of various sizes (Fig. 21). Marine species were represented by small individuals: plaice were between $15-25 \mathrm{~cm}$, cod were between $30-40 \mathrm{~cm}$ and turbot were between 30-50 cm long.

Data from identified fish bones from layer B indicate that Šventoji 2/4 was used as a freshwater fishing site at the end of the Subneolithic. The main catch of the last hunters-gatherers were medium size cyprinids and were mostly bream. It is important to note that results of our research are not consistent with zooarchaeological data from the trenches excavated in 1967-1995, according to which from 677 identified fish bones from layer B, pike bones made up $74.9 \%$, while cyprinid bones accounted for only $12.8 \%$ (Stančikaite 


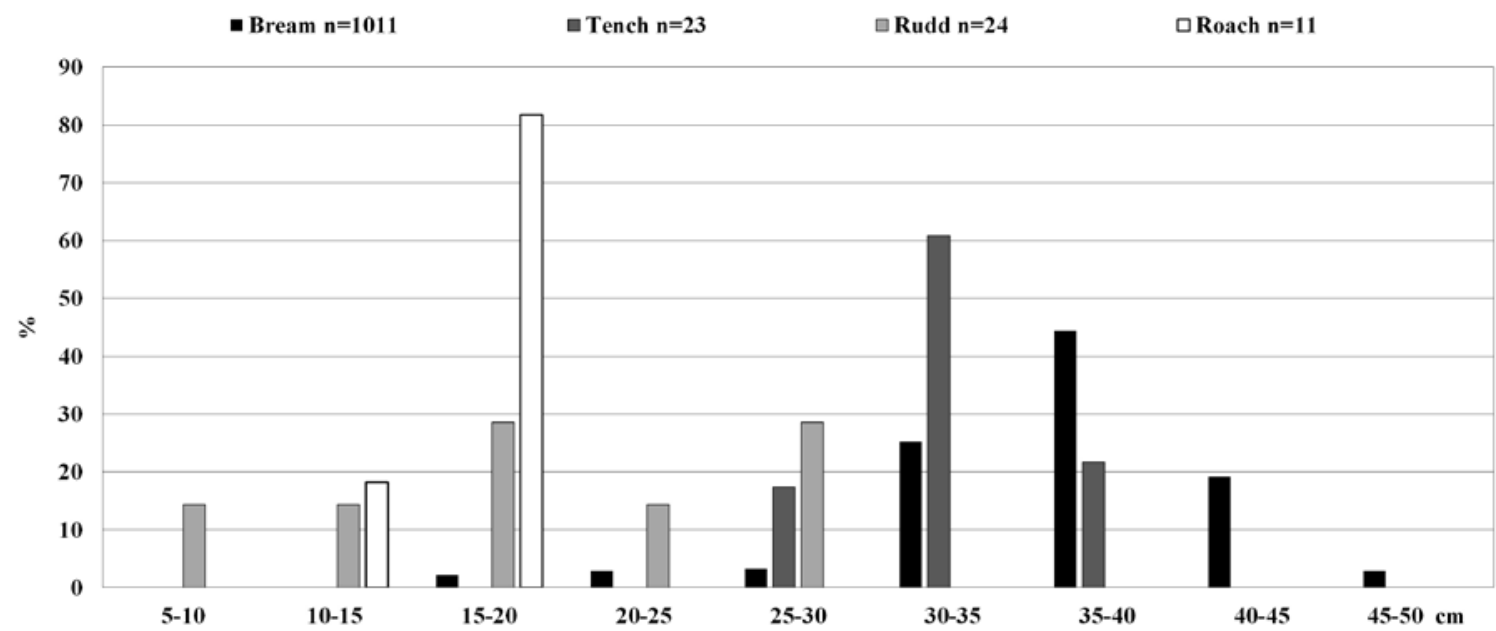

Fig. 21. Length of cyprinids from layer B of Šventoji 2/4. Compiled by G. Piličiauskienè.

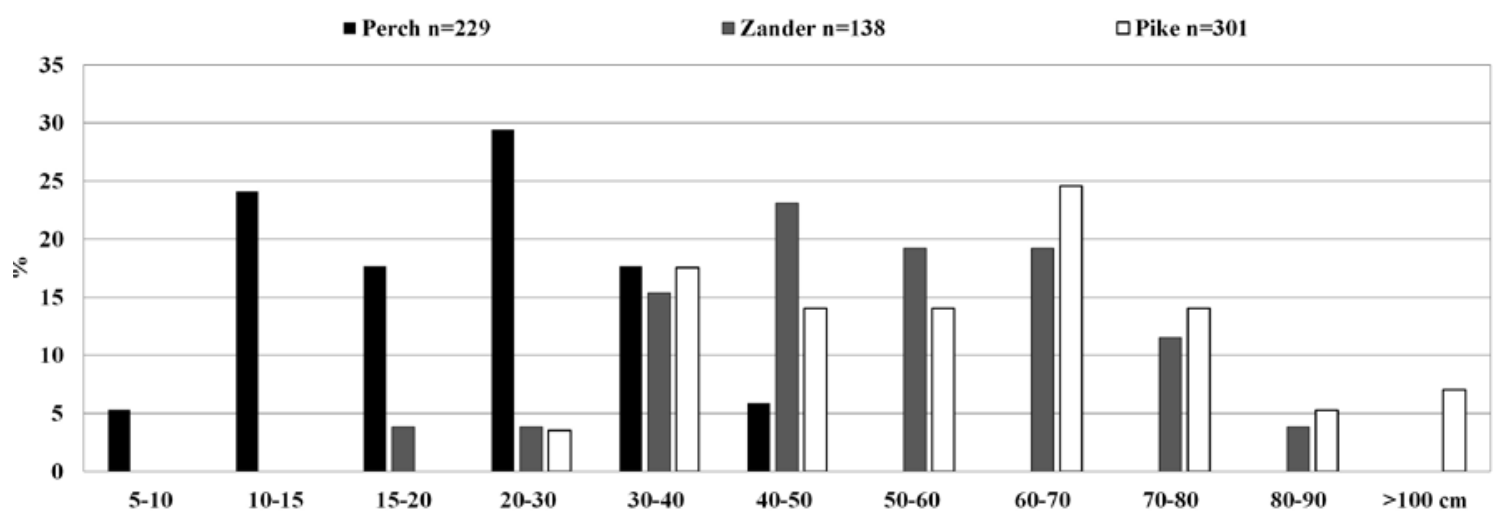

Fig. 22. Length of predatory fish species from layer B of Šventoji 2/4. Compiled by G. Piličiauskiené.

et al. 2009). Furthermore, previous data shows that mostly large and very large fish was caught at Šventoji 4 (Rimantienè 2005). This inconsistency between the previous and new zooarchaeological data results from the different field research methods used. During the 1967-1995 excavations, the majority of fish bones were collected by hand, while in 2014 the majority of fish bones were obtained by wet sieving the sediments through a $1 \mathrm{~mm}$ size mesh. Therefore, the most recent data is much more representative and includes the bones of smaller fish. This conclusion is supported by the investigations of the fish bone assemblage from the 1997-1998 excavations. In the 1997-1998 season, fish bones were also sieved from soil samples similar to the excavations in 2014 (Daugnora 2000). From the 578 identified fish bones found in layer B, bones of cyprinids made up $46 \%$, while pike accounted only for $10.7 \%$ (Stančikaitè et al. 2009), cyprinids dominated over pike just like in the assemblage from the 2014 excavations. Significant species-related changes that depend on the excavation techniques have been documented in many other cases (see Hamilton-Dyer et al. 2016 and references cited within).

Another interesting feature of the fish bone assemblage from layer $B$ is the unnatural predominance of cranial and fin bones over vertebrae. The most plausible explanation for this is that initial processing of freshly caught fish took place directly at the fishery. 
Fish heads and, possibly, entrails too were discarded into the water, while remaining parts of fish were transported to dwelling sites. Bones of very small fish including vertebrae could have entered the cultural layer together with the entrails of predatory fish. The question of the marine species found at Šventoji $2 / 4$, however, is more complicated. Turbot lives at a depth of 20-70 $\mathrm{m}$ and cod at a depth of 150-200 m (Muus, Dahlstrøm 1989). These taxa could have been caught further from the coast. The only way to catch them in prehistory was with a rod and line; however, no fishing hooks were found in any of Šventoji Subneolithic and Neolithic sites. It seems that bones of marine fish could have ended up at Šventoji 2/4 site together with seal entrails. Numerous seal metapodia and phalanx bones, as well as butchering marks on seal bones, provide evidence for seal butchering onsite (Piličiauskienè et al. in prep.).

The presence of ide (Leuciscus idus) at Šventoji 2/4 and other Šventoji sites requires a special explanation. We did not find any ide bones when analyzing the osteological material from the 2014 excavations. Likewise ide bones were not identified by J. Sloka in an earlier study (Rimantienè 1996b, X table). They are also absent among the fish bones from the 19971998 excavations identified by A. K. Hufthammer at the University of Bergen (Stančikaitè et al. 2009), and they were not reported among the fish bones from 1989-1990 excavations by Daugnora (2000) either. Ide bones are reported to be present almost in all assemblages from the older excavations at the Šventoji Subneolithic-Neolithic sites only in 2009 paper (Stančikaitè et al. 2009), most likely after the reanalysis of the fish bone collections by L. Daugnora. In regard to this information, we are sceptical about the validity of identified ide bones at Šventoji sites, although we are not able to verify our doubts because fish bone collections from older excavations are not available to us.

\section{CHRONOLOGY}

Today, 43 radiocarbon dates are available for Šventoji 2/4 and they put the site among the most extensively radiocarbon dated archaeological sites in Lithuania $^{5}$ (Table 6). However, very often the locations of ${ }^{14} \mathrm{C}$ dated samples were not reported precisely. On the other hand, not all ${ }^{14} \mathrm{C}$ dates are correct and not all correctly date the find layers because of the reservoir effect. The plot of calibrated ${ }^{14} \mathrm{C}$ dates gives a misleading impression that the site was continuously used for 1300 years (Fig. 23). However, this illusion will be exposed using data from the 2014 trench, stratigraphy and age-depth modelling of terrestrial ${ }^{14} \mathrm{C}$ dates.

Sixteen of the $43{ }^{14} \mathrm{C}$ dates obtained at Šventoji 2/4 were taken from samples collected in 2014 trench. Dating terrestrial and aquatic materials from the same contexts allowed for the estimation of the radiocarbon freshwater and marine reservoir effects, which contributed to the older age of a significant number of ${ }^{14} \mathrm{C}$ dates at Šventoji $2 / 4$. The freshwater reservoir effect, in the order of 320-510 yr, was estimated for the Šventoji lagoonal lake around $3000 \mathrm{cal}$ BC. The marine reservoir effect of $190 \pm 43 \mathrm{yr}$ was estimated for the southeastern coast of the Littorina Sea for the same period. We also documented that in addition to ${ }^{14} \mathrm{C}$ dates of fish and seal bones, the dates of charred food remains, and human and dog bones were also affected by the radiocarbon reservoir effects. This research has been published elsewhere further in detail (Piličiauskas, Heron 2015; Piličiauskas et al. 2017b). Having these significant aquatic reservoir effects in mind, we decided to not use radiocarbon dates that are or might be older due to aquatic reservoir effects when building site chronology.

The two oldest dates from the 2014 trench, Poz65441: $7040 \pm 40$ BP and Poz-65442: $6890 \pm 35$ BP, have been produced by twigs of unidentified wood

\footnotetext{
${ }^{5}$ Forty-four ${ }^{14} \mathrm{C}$ dates are available for Daktariške 5 site (Piličiauskas 2018).
} 


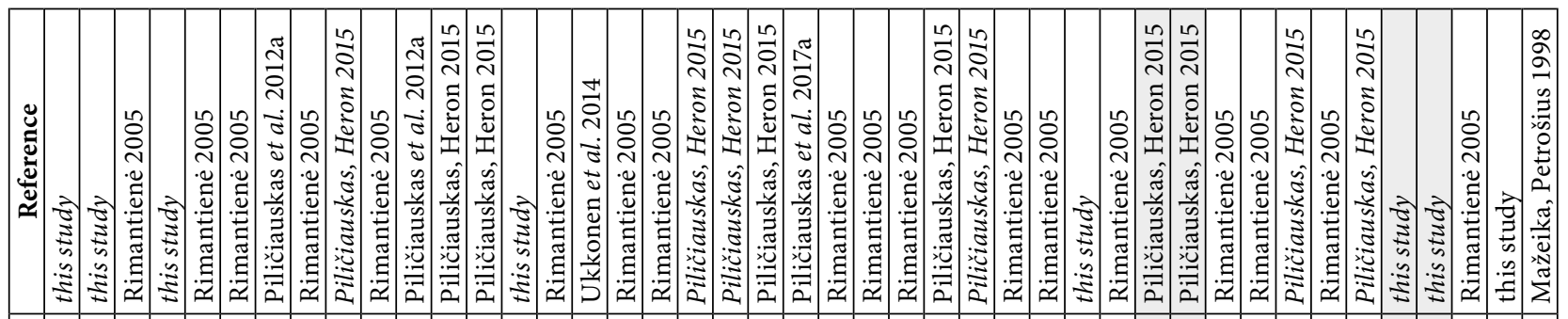

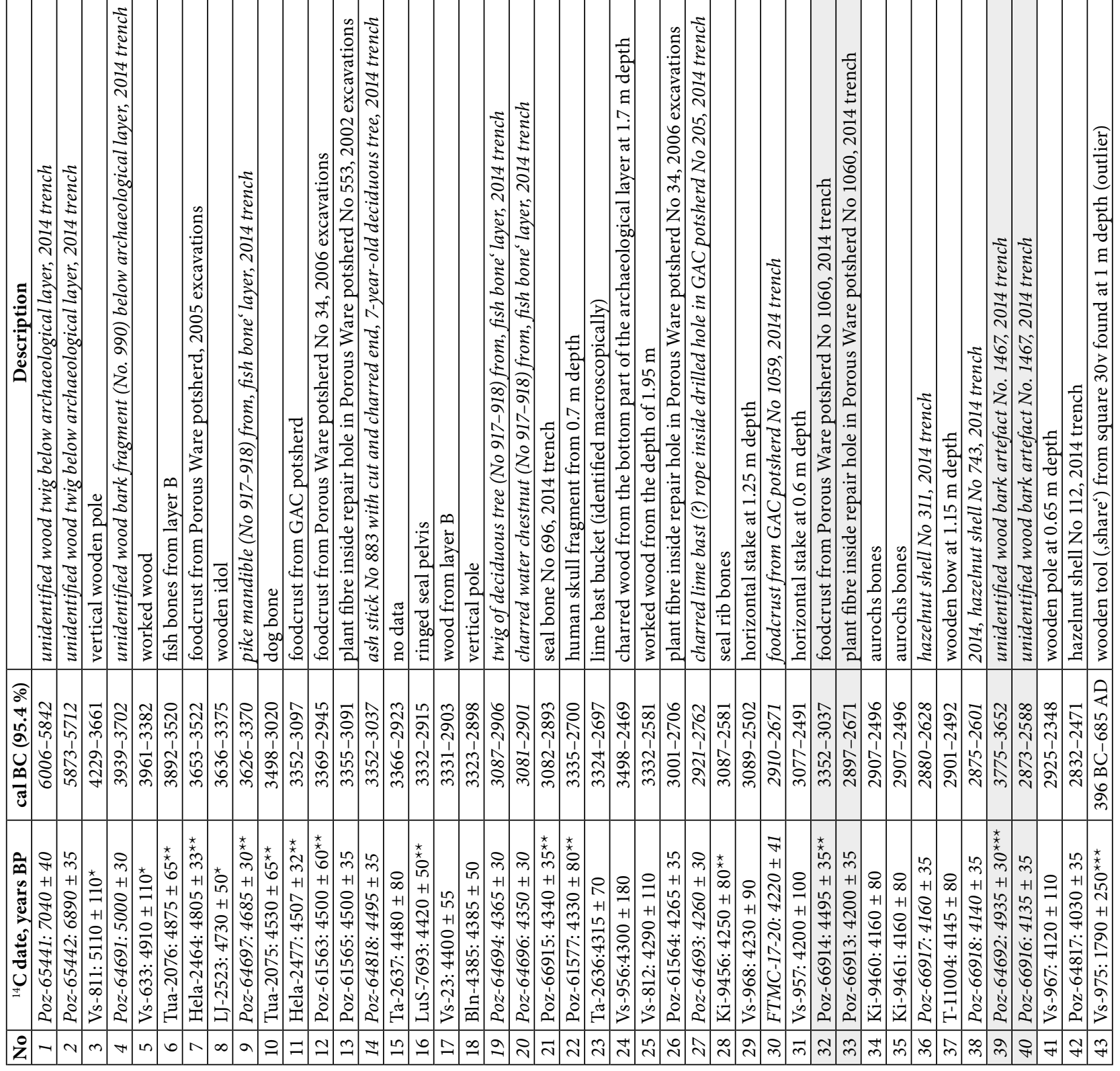

Table 6. ${ }^{14} \mathrm{C}$ dates from Šventoji 2/4. Dates obtained for samples from 2014 trench are indicated in Italic.

Paired dates obtained from the same potsherd and wooden artefact are shaded. ${ }^{*}$ - dates from wood, which may be older due to unknown factors; ${ }^{* *}-\mathrm{dog}$, seal, fish and human bone and charred food residue dates, which have been proved to be or might be older due to aquatic reservoir effects, ${ }^{\star * \star}$ - wood dates which are certainly outliers. 


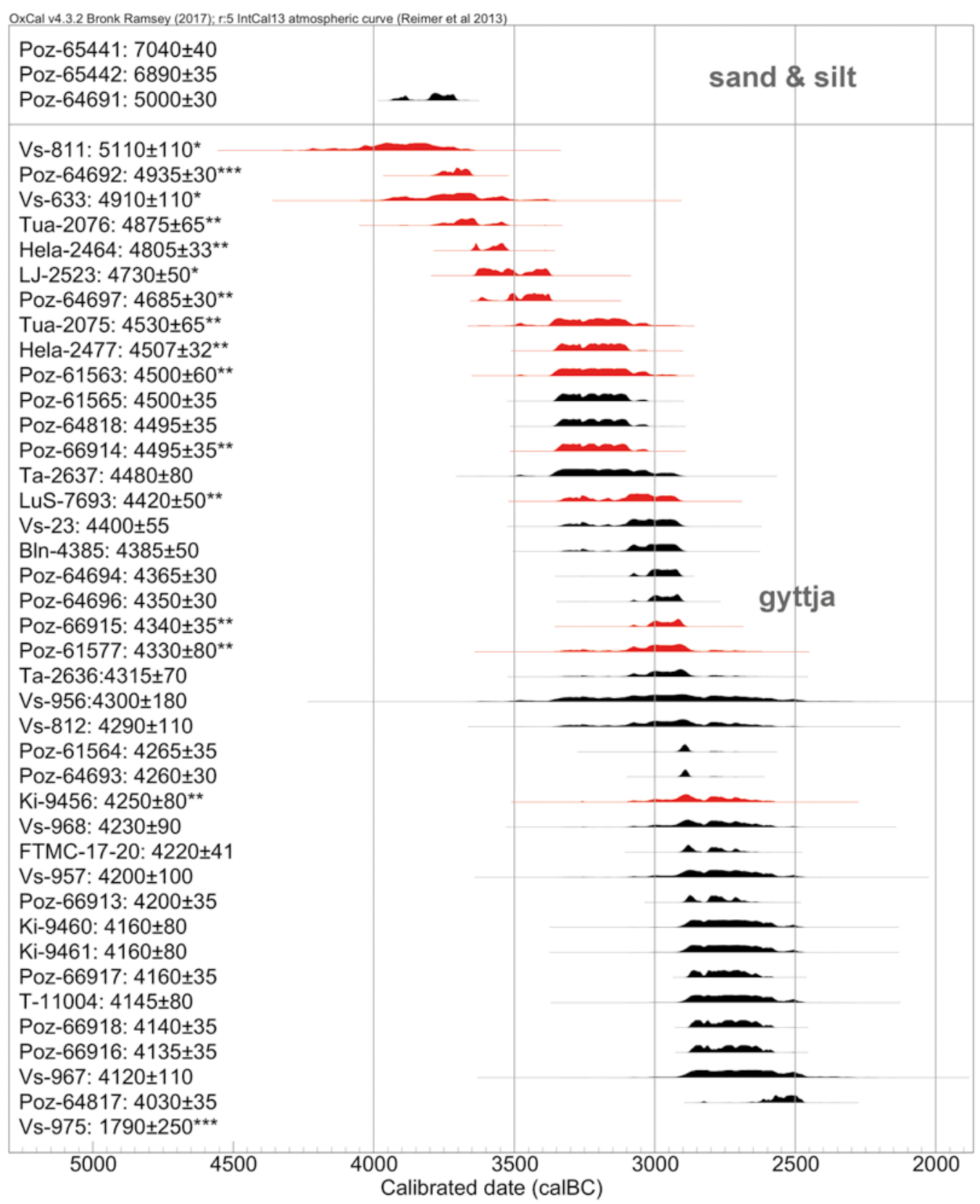

Fig. 23. Calibration plot of all ${ }^{14} \mathrm{C}$ dates available for Šventoji $2 / 4$ site. ${ }^{*}$ - dates from wood, which may be older due to unknown factors; ${ }^{* *}$ - dog, seal, fish and human bone and charred food residue dates, which have been proved to be or might be older due to aquatic reservoir effects, ${ }^{* * *}$ - wood dates which are certainly outliers. $95.4 \%$ probability ranges of certain and suspected outliers were coloured in red. Created by G. Piličiauskas.

recovered from marine sediment layers of silt and fine sand, lying below the archaeological layers. However, both dates do not represent the actual age of the sediment deposition (Fig. 4A). Their calibrated ages fall between 6000-5700 cal BC, but from the radiocarbon dates of paleosols and in situ standing tree stumps uncovered at other Šventoji sites, we know that the sea coastline was further to the west at that time (Piličiauskas et al. 2012; 2015). Radiocarbon dated wood twigs had to be redeposited from topsoil 


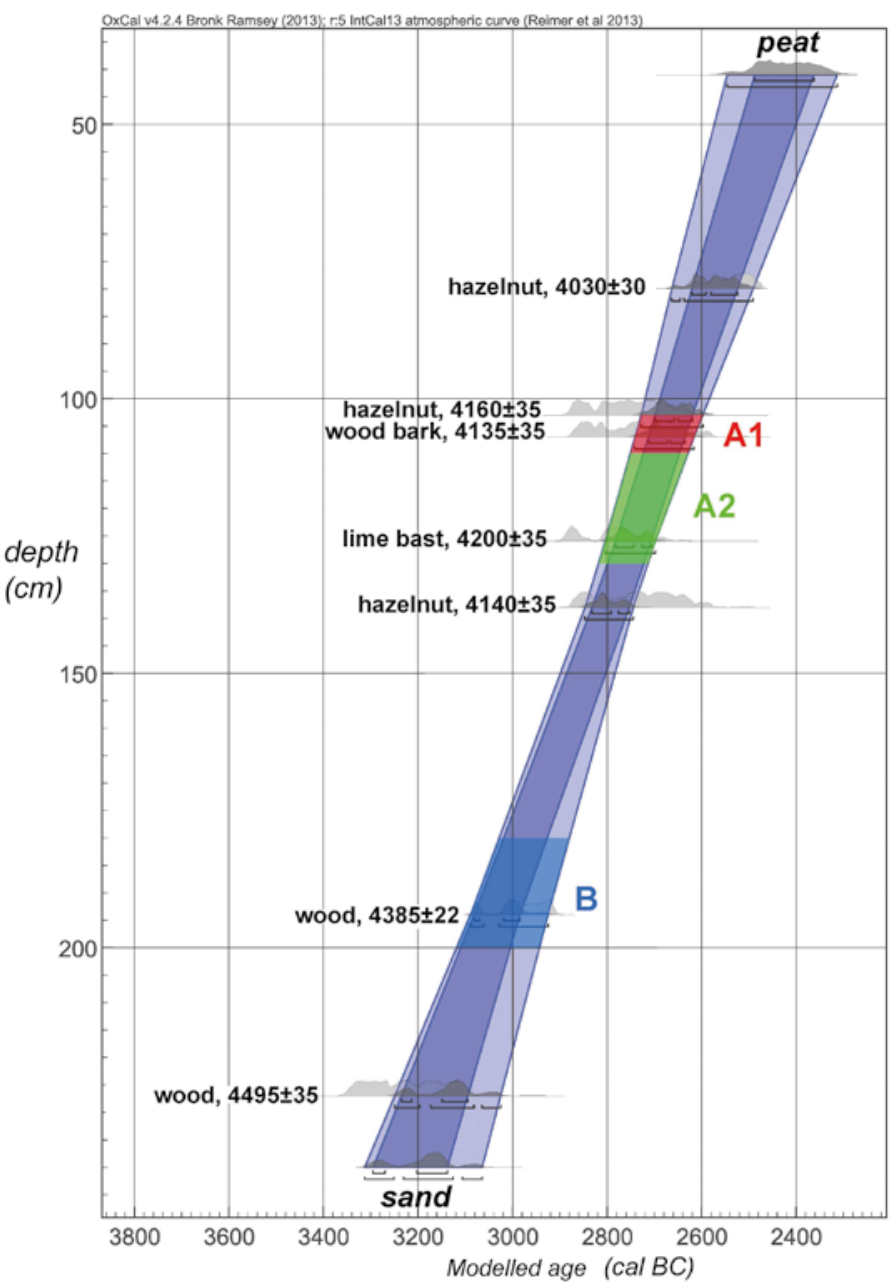

Fig. 24. Age-depth model compiled for lacustrine sediments (gyttja) at Šventoji $2 / 4$ site from ${ }^{14} \mathrm{C}$ dates of terrestrial samples from 2014 year's trench. Note that the depths of distinct cultural layers could not be defined very precisely because of the low density of potsherds. A projection of ${ }^{14} \mathrm{C}$ dates from samples collected at various places of the trench into a single column may introduce additional error. Created by G. Piličiauskas.

or peat layers, which were eroded by advancing sea water. Only a few hundred years later, the dated plant fragments became trapped within the silt and sand at the bottom of the sea. It probably occurred ca. 5000 cal $\mathrm{BC}$ during the maximum transgression of the Littorina Sea.

Among the new ${ }^{14} \mathrm{C}$ dates presented in this paper, we immediately took care to note, test, and finally prove that one of the dates was a clear outlier. The date Poz-64692: $4935 \pm 30 \mathrm{BP}$ of bark artefact No 1467 was older than the hazelnut shell dates from the same depth by about 800 yr. There was only a slight possibility that this artefact has been rewashed from older deposits and redeposited in gyttja. However, after re-dating it in the same lab, the correct date was obtained - Poz-66916: $4135 \pm 35$, which was consistent with the context dates. Unfortunately, our efforts together with the head of the lab to find out the source of the error gave no results.

One of the most important tasks was the building of the age-depth model. It was required in order to date the 3 archaeological layers documented. It also was helpful in order to gain a more precise dating of the pottery transition from the Subneolithic to Neolithic, since the transition coincided with the large plateau of 2880-2580 cal BC in the calibration curve. Firstly, all terrestrial ${ }^{14} \mathrm{C}$ dates were projected onto the profile of the trench (Fig. 4A). Then, $7{ }^{14} \mathrm{C}$ dates were projected into a single column in the middle part of the trench, while trying to keep them within the same horizon. A projection point was chosen in the middle part of the trench, as most of the samples for ${ }^{14} \mathrm{C}$ dating concentrated there and because it required the least distance during projection. Relative depths of projected dates were calculated from the profile and an age-depth model was created using OxCal v4.2.4 software. A constant sedimentation rate was chosen for modelling as the amount and spatial information of projected dates was not sufficient and precise enough to reveal changes in sedimentation rate. When archaeological layers were superimposed on the age-depth model, their durations became quantifiable with the different probability ranges (Fig. 24). After the extrapolation of modelled age to the bottom and the top of the 
gyttja, the estimation of rate and duration of gyttja deposition also became possible.

Using the compiled age-depth model (Fig. 24), it was estimated that gyttja was accumulating from 3290/3130 until 2490/2370 cal BC. Assuming a constant rate of sedimentation, 2 meters of gyttja had to have accumulated in about 800 years with $2.5 \mathrm{~mm}$ of sediment deposited every year. The older archaeological layer B may have accumulated in 80 years and dates to $3110 / 3000-3020 / 2930 \mathrm{cal} \mathrm{BC}$. Then, a break in human activity for about 200 years is indicated by a $0.5 \mathrm{~m}$ thick gyttja containing very few artefacts and no pottery. The next archaeological layer (A2) then follows, which accumulated in another 80 years and dates to $2800 / 2720-2720 / 2650 \mathrm{cal} \mathrm{BC}$. And finally, it was covered by a thin Neolithic layer A1 which dates to 2720/2650-2700/2620 cal BC and perhaps accumulated in the span of only two or three decades. However, the model does not necessarily show the real duration of the GAC phase in Šventoji, which may have been longer. During older excavations at Šventoji 2/4, thicker GAC layers with more abundant pottery have been uncovered (Rimantiene 2005, Fig. 13). The lake became overgrown until 2490/2370 cal BC, although deposition of human waste ceased several hundred years before.

The age-depth model confirms that Šventoji $2 / 4$ was contemporaneous with dwelling sites on the eastern bank of lagoonal lake, namely Šventoji 23 and 26, dating to 3200-2600 cal BC (Piličiauskas 2016). This observation is important for interpreting site function and reconstructing settlement systems. Furthermore, the age-depth model raises doubts about some of the ${ }^{14} \mathrm{C}$ dates obtained from the wood artefacts from Šventoji 2/4. An extrapolated age suggests that gyttja deposition started ca. $3200 \mathrm{cal}$ BC. Three dates of wooden artefacts found in the gyttja are older than $3200 \mathrm{cal} \mathrm{BC}-$ Vs-811: $5110 \pm 110 \mathrm{BP}$ (4229-3661 cal BC), Vs-633: $4910 \pm 110$ BP (3961-3382 cal BC) and LJ-2523: $4730 \pm 50 \mathrm{BP}(3636-3375 \mathrm{cal} \mathrm{BC})$. Theoretically, these dates may be correct and the extrapolated age of the beginning of gyttja deposition may be too young, since the age-depth model did not consider a possibility that the oldest gyttja might have been eroded, perhaps several times, by resumed water flow, which is demonstrated by lenses of gravelly sand, documented in the bottom part of gyttja (Fig. 4A). However, in this case, we acknowledge that all three wooden artefacts, including the famous wooden idol (Rimantiene 2005, cover picture), are not related to the oldest archaeological layer B, but predate it. A good example of this possibility is the antler elk staff found within the same paleochannel at Šventoji 3, which is located nearby. The staff has been recently dated to (KIA-51366) $4766 \pm 31 \mathrm{BP}(3640-3510 \mathrm{cal}$ BC) (Iršènas et al. 2018). The researcher described that it was found 'in the very bottom of the lake', which means that it came from the very bottom of gyttja (Rimantiene 1979). However, some other arguments further strengthen the doubts on the correctness of the oldest wood dates at Šventoji 2/4. One of them is the very large uncertainty $( \pm 110)$ of Vs-811 and Vs-633 dates. An even larger uncertainty of $\pm 250 \mathrm{yr}$ has been measured for another date from Šventoji 2/4 - Vs-975: $1790 \pm 250$ BP (396 BC$685 \mathrm{AD}$ ). The dated wooden tool was found in gyttja at a depth of $1 \mathrm{~m}$, while the age-depth model shows that gyttja's deposition stopped around $2400 \mathrm{cal} \mathrm{BC}$ instead of in Iron Age (Fig. 24). It is very likely that in all cases with larger uncertainties the amount of carbon was not enough to obtain a correct ${ }^{14} \mathrm{C}$ date. The date of wooden idol LJ-2523: $4730 \pm 50,3636-$ 3375 cal BC was made in Scripps (UCSD) La Jolla laboratory (USA) in about 1980. Only two samples from Šventoji were dated in this lab. And the second one, a wooden pile or stick from Šventoji 1, also yielded an older age (LJ-2528: $4640 \pm 60 \mathrm{BP}, 3633-$ $3123 \mathrm{cal} \mathrm{BC)}$ compared to the dates made at other labs, the medians of which are between 3200 and 2400 cal BC (Rimantienè 2005). 


\section{NATURAL HISTORY OF THE SITE}

The available geological and paleoecological data enables us to reconstruct the natural history of the Šventoji $2 / 4$ site area. Until $\sim 5000$ cal BC, the area of Šventoji $2 / 4$ was a dryland, covered by forests and bogs. Paleosols dating to this period are found in many places in Šventoji, sometimes with tree stumps still standing in situ (Piličiauskas et al. 2012b). However, at Šventoji 2/4 ancient paleosols were eroded during the maximal transgression of Littorina Sea ca. 5000 cal BC. During this period silt and fine sand with remains of Macoma balthica, Cardium edule, and Mytilus edulis were deposited (Fig. 4 and 5).

The regression of the Littorina Sea began in 4750$4500 \mathrm{cal} \mathrm{BC}$ in the southeastern part of the sea. It transformed the littoral zone, firstly into an open bay (diatom sample DT3) and then later into a lagoon (DT4 and 5), with only a limited connection to the sea. Prevailing fresh-brackish benthic diatoms (Epithemia turgida, E. adnata) indicate mainly freshwater and a shallow, calm sedimentary environment. A few percent of brackish benthic Diploneis smithii var. rhombica and Campylodiscus clypeus diatoms means that this water body had a connection with the sea and a small inflow of brackish water existed. This correlates well with plant macrofossil data. The species of shallow-water habitats are dominating among macrophytes. Some of them are halophytes (Ruppia maritima, Salicornia europaea), which spread in the brackish bodies of water or marshes in the coastal areas.

At ca. 3500 cal BC the research area became a dryland, although dryland deposits did not survive. Evidence for the dryland period comes from the main and most interesting geological feature at Šventoji $2 / 4$ - the paleochannel. A fragment of its bed, $0.5 \mathrm{~km}$ long and $50-60 \mathrm{~m}$ wide, is visible in the modern landscape (Fig. 2). The 2014 trench and boreholes revealed the topography of its bottom and documented its fill (Fig. 4 and 5). The paleochannel is up to $2.5 \mathrm{~m}$ deep, and it was rapidly sculpted within lagoonal and marine sediments by a powerful flow of water. There are almost no alluvial deposits left by this event with the exception of a thin and discontinuous gravel interlayer, intruded in between marine sand and lacustrine gyttja (Fig. 5). It was most likely caused by the abrupt draining of the large lagoonal lake, which rose above the level of the Littorina Sea because of the ongoing post-glacial fluctuations in the earth's crust. This occurred sometime between 3700 and $3300 \mathrm{cal} \mathrm{BC}$.

Very soon after the formation of the erosional channel, accumulation of mainly freshwater gyttja started within it as well as on its banks. Sedimentation of gyttja continued for 800 years, 3290/3130 2490/2370 cal BC. Trapa natans as well as Bithynia tentaculata, Sphaerium solidum and Unio sp. are indicators of a shallow and warm freshwater basin, while few lenses of coarse or gravelly sand embedded within the lower part of gyttja point to occasional flows. Predominant freshwater-brackish planktonic (Aulacoseira ambigua, A. granulata) and epiphytic (Pseudostaurosira brevistiata) diatoms confirm a shallow, almost freshwater sedimentary environment. Fresh water inflow to the lake prevailed, but a small amount of brackish benthic diatoms in the sediments indicate a constant, although insignificant inflow of brackish water from the sea. All halophytes disappeared from the macroflora. Nymphaea alba, Najas marina and Potamogeton perfoliatus prevailed among the water plants. At the same time, shoreline plants (Typha latifolia, Schoenoplectus lacustris) and plants of dampish, nutrient rich habitats (Urtica dioica, Persicaria lapathifolia) started to spread. It is possible that small muddy islands existed along the edges of the paleochannel. Around $2400 \mathrm{cal} \mathrm{BC}$, the paleochannel was filled with gyttja almost to the brim, and the lake became entirely overgrown, at least at Šventoji 2/4. After that, the formation of peat began. 


\section{CULTURAL HISTORY AND SITE FUNCTION}

The oldest signs of human occupation in the Šventoji area are known from higher lying riverine sites and not from lagoonal/lacustrine sites, since lagoons only formed later on. A Late Mesolithic pithouse has been recently excavated at Šventoji 40 and dated to ca. $6000 \mathrm{cal} \mathrm{BC} \mathrm{(Piličiauskas} \mathrm{2018).}$ Šventoji 2/4 had to be dryland at the time, but the paleosol with all of its potential remains of human activities have been removed by the maximal transgression of the Littorina Sea ca. $5000 \mathrm{cal} \mathrm{BC}$. During ca. 4000-3500 cal BC, the Šventoji 2/4 area was in the middle of the lagoon because of the sea regression. The eastern bank of this lagoon was occupied by Comb Ware people, as has recently been demonstrated by the excavations at Šventoji 43 (Piličiauskas et al. 2019). Sediments of this lagoon remained almost uninvestigated at Šventoji 2/4. However, in the 2014 trench, a concentration of pike bones was documented, which was clearly embedded into a laminated lagoonal sediment and not within lacustrine gyttja. It is unclear whether it is of natural or anthropogenic origin, but it would be sensible to expect to find some archaeological finds at the bottom of the lagoon, where Comb Ware people fished pike and zander (Piličiauskas et al. 2019).

People definitely appeared at Šventoji $2 / 4$ soon after the formation of the paleochannel ca. $3500 \mathrm{cal}$ BC. However, wooden artefacts from the bottom part of the gyttja are very few and pottery is completely absent (Fig. 4B). These finds reflect only episodic activities. This picture of very limited activity at the site changed considerably in 3110/3000-3020/2930 cal BC when enormous numbers of freshwater fish bones were deposited on the northwestern slope of the paleochannel together with other human waste (Fig. 4B). During this period, Šventoji 2/4 was used for extensive fishing of freshwater taxa, mostly bream (Abramis brama), pike (Esox lucius), perch (Perca fluviatilis), and zander (Sander lucioperca).
Gyttja also accumulated on the banks of the paleochannel, although it survived unploughed only at isolated locations. This means that the banks were permanently or repeatedly flooded by water. It is most likely, that the paleochannel became the deepest part of a large and very shallow lagoonal lake. Consequently, it had less vegetation and was preferred by migrating and wintering fish as well as by travelling and fishing people. The water was fresh and stagnant or sluggish and the lake was fed by Šventoji River.

Three explanations for the formation of Šventoji 2/4 have been previously suggested. Rimantienè once hypothesized that settlements existed on the bank of the paleochannel and their finds were washed down and transported to its bed by the transgressing Littorina Sea (Kabailienè, Rimantienè 1998). Concurrently, the site was interpreted as a fishing station, which accumulated large amounts of human waste left during fishing expeditions (Rimantienè 1996a; 2005). And finally, the idea of a pile dwelling was suggested by A. Girininkas (2005). Our research, however, supports the idea of a fishing station, which existed at some distance from the dwelling area. No signs of settlements dated to the Subneolithic have been found on the banks of the paleochannel, despite hundreds of test pits that have been excavated there (Fig. 2). Thin and very few poles were most likely used for fishing or boating and not for the building of pile dwellings. No remains of wooden platforms have been found either. The almost complete absence of amber, flint, and stone processing debitage is not compatible with the function of habitation. The wooden and bone tools found are mostly related to fishing activities. Many different fishing methods were employed, as is shown by remains of logboats, paddles, fish spears, fish fences, and baskets. Subneolithic fishermen clearly preferred the northwestern part of the paleochannel for their activities as it was deeper and had a steeper slope (Fig. 5). Human waste, which could not be related to fishing directly, was deposited 
at Šventoji 2/4 mostly during fishing trips. However, deliberate transportation of human waste collected at dwelling sites and its discard directly at fisheries seems possible. Dene people in Canada transported their dwelling waste to fisheries, which sometimes were situated $19 \mathrm{~km}$ from their houses (Janes 1983). The distance between the Šventoji 2/4 fisheries and contemporary habitation sites on the eastern bank of the lagoonal lake is only between $1.5-2 \mathrm{~km}$. The discard of settlement waste at fishing stations may involve both rational and ritual aspects.

Subneolithic fishing at Šventoji 2/4 may have taken place over hour-long visits or visits that lasted a few days. They also regularly installed and repaired fishing weirs and nets, collected the catch, and performed the initial processing of the catch. Zooarchaeological data shows that the main catch was of medium size cyprinids. Heads (and perhaps guts) of fish were removed on the spot and thrown back in the water. Only then, the catch was ready for transport to the dwelling sites situated on the eastern bank of the lake, for instance Šventoji 23 and 26. However, in $3020 / 2930$ cal BC fishing ceased in the whole area of the paleochannel for about 200 years until after the deposition of layer A. The gap of about 0.5 meters between the lower and the upper archaeological layers was documented not only at Šventoji $2 / 4$, but also at Šventoji 1 (Rimantienè 2005). There is no evidence for any dramatic environmental change during that period. The Subneolithic fishermen abandoned the Šventoji region for reasons unknown. Perhaps the first groups of Neolithic people may have entered the region already in 3020/2930-2800/2720 cal BC, although we have no direct proof of this, and it is difficult to speculate that the arrival of Neolithic migrants would have caused a break in the exploitation of the fisheries at Šventoji 2/4. In 2800/2720-2720/2650 cal BC, Subneolithic fishermen returned back to Šventoji 2/4. However, the paleochannel was not the same as 200 years before. The lake was shallower and perhaps fish were not as abundant. We may assume that the Šventoji River found another way into the sea before the abandonment of the site. As a result, the Subneolithic layer A2 contains much less fish bones when compared to layer B. However, a large quantity of hazelnut shells were recovered in layer A2, which were almost absent in layer B. It seems that hazelnuts became a preferred snack for the Subneolithic fishermen during the formation of layer A2.

In 2720/2650 cal BC, Subneolithic Porous Ware pottery was replaced by Neolithic Globular Amphora Ware at Šventoji 2/4. This event coincides with the boundary between horizons A1 and A2. GAC people in the southeastern Baltic were raising domestic animals and consuming dairy products. However, aquatic resources were still frequently prepared in ceramic vessels. Food residue analysis has shown that freshwater fish were being processed in GAC vessels at Šventoji 2/4, although together with ruminant adipose and dairy products (Robson et al. 2019; Piličiauskas et al. 2018). However, fish bones were either very few or absent in layer A1 (Fig. 4B). It may indicate two changes. The initial processing of the catch directly at the fishery may have not been practised by GAC people. On the other hand, the catch may have become much smaller than in previous periods.

According to data from the 2014 trench, the GAC fishery existed at Šventoji 2/4 for a very short period, which did not exceed one hundred years (2720/26502700/2620 cal BC). However, we know from older excavations that in some places GAC potsherds were found in a thicker layer, which may have been deposited over several hundred years (Fig. 13). The end of human waste deposition in the gyttja is marked by a thin horizon of a lighter-coloured gyttja, which contained more clay (Fig. 4). The same interlayer of clayey gyttja has also been documented 200 meters to the northeast from the 2014 trench on the opposite side of paleochannel (Kuriliene et al. 2016). It is clear that some temporal change of sedimentation occurred in the environment over a wide area of the former lake. 
However, it is hard to say what caused it, whether or how it was related to the cessation of human activities at Šventoji 2/4. The lake continued to exist even after the end of human activities for 200 years until it finally became overgrown in ca. $2400 \mathrm{cal}$ BC. People returned to this boggy area only somewhere between 2400 and $2000 \mathrm{cal} \mathrm{BC}$ and only to a very restricted area of the site. At this time, a dwelling site or amber workshop was established on the dry gyttja on the northwestern bank of the paleochannel. It was identified from the clusters of flints and amber waste as well as from small fireplaces uncovered in 2006 (Brazaitis 2007). These remains were not yet radiocarbon dated, but the pottery found is classified as post-Corded Ware due to its mineral temper and cord ornamentation. It may have been produced in 2400-2000 cal BC. However, no bones were preserved in the dry archaeological layer of the post-Corded Ware settlement.

\section{CONCLUSIONS}

The exceptional preservation of archaeological remains at Šventoji 2/4 site was influenced by its very special function and topography. The site was used for several centuries by Subneolithic and Neolithic fishermen as a fishing station in the middle of the lagoonal lake. The site tells a story about the extraordinary scale, diverse methods, and elaborate strategies of fishing used by the last Subneolithic and first Neolithic people in coastal Lithuania. Šventoji $2 / 4$ confirms that the GAC people were the first to bring Neolithic pottery, ideology, and stock-breeding to the Šventoji region. However, at the same time it demonstrates that the first Neolithic people in coastal areas continued to exploit the same fisheries that were intensively used by Subneolithic people. This may be considered as evidence that local hunters-gatherers joined Neolithic communities and ensured some economic continuity between the Subneolithic and Neolithic despite the radical changes in production of pottery.

\section{Acknowledgements}

We are thankful to Lembi Lõugas for assistance in the identification of fish bone taxa. We are also thankful to the two anonymous reviewers and Annette Hansen for their useful remarks and comments that helped improve the quality of this manuscript.

\section{REFERENCES}

Ahlqvist, A., 2007. The Finno-Ugrian Hydronymic Stem Voi- as a Reflex of the Former Area of Distribution of the Water Chestnut (Trapa natans). Helsinki: Department of Slavonic and Baltic Languages and Literatures.

Barinova, S. S., Medvedeva, L. A., Anissimova, O. V., 2006. Diversity of algal indicators in environmental assessment. Tel-Aviv: Pilies Studio.

Battarbee, R. W., 1986. Diatom analysis. In: Berglund, B., ed. Handbook of Holocene Paleoecology and Paleohydrology. Chichester: Wiley \& Sons, 527-570.

Berggren, G., 1969. Atlas of Seeds and Small Fruits of Northwest-European Plant Species with Morphological Descriptions, Part 2, Cyperaceae. Lund: Berlingska Boktryckeriet.

Berggren, G., 1981. Atlas of Seeds and Small Fruits of Northwest-European Plant Species with Morphological Descriptions. Part 3, SalicaceaeCruciferae. Stockholm: Swedish Museum of Natural History.

Bērzin̦š, V., 2008. Sārnate: living by a coastal lake during the East Baltic Neolithic, Acta Universitatis Ouluensis B, Humaniora 86. Oulu: Oulun Yliopisto.

Brazaitis, D., 2007. Šventosios 1-osios, 4-osios, 36-osios radimviečių ir jų aplinkos tyrinėjimai. ATL 2006 metais, 35-42.

Cappers, R. T. J., Bekker, R. M., Jans, J. E. A., 2006. Digital Seed Atlas of the Netherlands. Eelde: Barkhuis Publishing \& Groningen University Library. 
Damušytè, A., 2011. Lietuvos pajūrio geologiné raida poledynmečiu. (Daktaro disertacija). (Post-Glacial Geological History of the Lithuanian Coastal Area. Doctoral Dissertation). Vilnius: Vilnius University.

Daugnora, L., 2000. Fish and seal osteological data at Šventoji sites. $L A, 19,85-101$.

Girininkas, A., 2005. Ar buvo polinių gyvenviečių akmens amžiuje Lietuvoje? Lituanistica, 62 (2), 33-45.

Glöer, P., Meier-Brook, C., 1998. Süsswassermollusken. Hamburg: Deutscher Jugendbund fur Naturbeobachtung.

Grigas, A., 1986. Lietuvos augaly vaisiai ir séklos. Vilnius: Mokslas.

Grimm, E.C., 1991-2011. TILIA software version 1.5.12. Illinois State Museum, Research and Collection Center, Springfield, USA.

Gurskas, A., 2010. Lietuvos moliusku katalogas. Kaunas: Lututè.

Hamilton-Dyer, S., Brisbane, M., Maltby, M., 2016. Fish, feather, fur and forest: exploitation of wild animals in medieval Novgorod and its territory. Quaternary International, 460, 97-107.

Iršènas, M., Butrimas, A., Rimkus, T., Slah, G., 2018. The Elks of Šventoji: taking another closer look. Archaeologia Baltica, 25, 125-139.

Janes, R.R., 1983. Archaeological etnography among Mackenzie basin Dene, Canada. Technical Paper 28. Calgary: Arctic Institute of North America.

Juodagalvis, V., Simpson, D.N., 2000. Šventoji revisited - the joint Lithuanian-Norwegian project. LA, 19, 139-151.

Kabailienè, M., Rimantienè, R., 1998. Holocene Changes in the Palaeoecological Conditions of the Lithuanian Coast around the Šventoji Settlement. Pact, 50 (II.10), 185-196.

Kessel, H., 1958. Neue Angaben über die Fauna subfossiler und recenter Mollusken der Esthnischen SSR. Geologia Instituudi Uurimused, III, 253-268.
Koivisto, S., 2012. Subneolithic fishery from the Iijoki river estuary, Northern Ostro-bothnia, Finland, Journal of wetland archaeology, 12, 22-47.

Krammer, K, Lange-Bertalot, H., 1986-1991. Bacillariophyceae, 1-4 Teil. In: Ettl, H., Gerloff, J., Heynig, H., Mollenhauer, D., eds. Süßwasserflora von Mitteleuropa, Band 2. Stuttgart/Jena: Gustav Fischer Verlag.

Kurilienè, A., Piličiauskas, G., Vengalis, R., 2016. Žvalgomieji tyrimai Šventosios senovès gyvenvieteje. ATL 2015 metais, 47-53.

Lozovski, V., 1999. Archaeological and ethnographic data for fishing structures. In: Coles, B., Coles, J., Jorgensen, M. S., eds. Bog bodies, sacred sites and wetland archaeology, Proceedings of a conference held by WARP and the National Museum of Denmark, in conjuction with Silkeborg Museum, Jutland, September 1996. Exeter: WARP, 139-145.

Muus, B. J., Dahlstrøm, P., 1989. Havfisk og Fiskeri i Nordvesteuropa. København: GEC Gads Forlag.

Oleninas, S., Daunys, D., Labanauskas, V., 1996. Lietuvos priekrantès dugno biotopų klasifikavimo principai. Geografijos metraštis, XXIX, 218-231.

Piličiauskas, G., 2016. Lietuvos pajūris subneolite ir neolite. Žemès ūkio pradžia. $L A, 42,25-103$.

Piličiauskas, G., 2018. Virvelinès keramikos kultūra Lietuvoje 2800-2400 cal BC. Vilnius: Lietuvos istorijos institutas.

Piličiauskas, G., Lavento, M., Oinonen, M., Grižas, G., 2011. New ${ }^{14} \mathrm{C}$ dates of Neolithic and Early Metal period ceramics in Lithuania. Radiocarbon, 53 (4), 629-643.

Piličiauskas, G., Mažeika, J., Gaidamavičius, A., Vaikutienè, G., Bitinas, A., Skuratovič, Ž., Stančikaité, M., 2012. New archaeological, paleoenvironmental, and ${ }^{14} \mathrm{C}$ data from Šventoji Neolithic sites, NW Lithuania. Radiocarbon, 54(3-4), 1017-1031.

Piličiauskas, G., Kisielienè, D., Piličiauskienè, G., Gaižauskas, L., Kalinauskas, A., 2019. Comb Ware culture in Lithuania: new evidence from Šventoji 43. LA, 45, 61-97. 
Piličiauskas, G., Heron, C., 2015. Aquatic radiocarbon reservoir offsets in the Southeastern Baltic. Radiocarbon, 57(4), 539-556.

Piličiauskas, G., Luik, H., Piličiauskienè, G., 2015. Reconsidered Late Mesolithic and Early Neolithic of the Lithuanian coast: the Smelte and Palanga sites. Estonian journal of archaeology, 19(1), 3-28.

Piličiauskienè, G., Piličiauskas, G., Gaižauskas, L., Peseckas, K., 2015. Archeologiniai tyrimai Šventojoje. ATL 2014 metais, 63-68.

Piličiauskas, G., Kisielienè, D., Piličiauskienè, G., 2017a. Deconstructing the concept of Subneolithic farming in the southeastern Baltic. Vegetation History and Archaeobotany, 26(2), 183-193.

Piličiauskas, G., Piličiauskienè, G., Jankauskas, R., Dupras, T., 2017b. Reconstructing Subneolithic and Neolithic diets of the inhabitants of the SE Baltic coast (3100-2500 cal BC) using stable isotope analysis. Archaeological and Anthropological Sciences, 9(7), 1421-1437.

Piličiauskas, G., Skipitytė, R., Heron, C., 2018. Mityba Lietuvoje 4500-1500 cal BC maisto liekanų keramikoje bendrųjų mėginių izotopinių tyrimų duomenimis. $L A, 44,9-41$.

Rimantienè, R., 1979. Šventoji. Narvos kultūros gyvenvietès. Vilnius: Mokslas.

Rimantienè, R., 1980. Šventoji. Pamarių kultūros gyvenviete. Vilnius: Mokslas.

Rimantienè, R., 1996a. Šventosios 4-oji radimvietè. $L A, 14,5-79$.

Rimantienè, R., 1996b. Akmens amžius Lietuvoje. Vilnius: Žiburio leidykla.

Rimantienè, R., 2005. Die Steinzeitfischer an der Ostseelagune in Litauen. Vilnius: National Museum of Lithuania.

Robson, H. K., Skipitytè, R., Piličiauskienè, G., Lucquin, A., Heron, C., Craig, O. E., Piličiauskas, G., 2019. Diet, cuisine and consumption practices of the first farmers in the south-eastern Baltic. Archaeological and Anthropological Sciences, 11(8), 4011-4024.
Schoch, W., Heller, I., Schweingruber, F. H., Kienast, F., 2004. Wood anatomy of central European Species. Online version: www.woodanatomy.ch.

Šivickis, P., 1960. Lietuvos moliuskai ir ju apibüdinimas. Vilnius: Valstybinè politinès ir mokslinès literatūros leidykla.

Snoeijs, P. ed. 1993. Intercalibration and distribution of diatom species in the Baltic Sea, vol.1. The Baltic marine biologists publication, 16a. Uppsala: Opulus press.

Snoeijs, P., Vilbaste, S. eds. 1994. Intercalibration and distribution of diatom species in the Baltic Sea, vol. 2. The Baltic marine biologists publication, $16 \mathrm{~b}$. Uppsala: Opulus press.

Snoeijs, P., Potapova, M. eds. 1995. Intercalibration and distribution of diatom species in the Baltic Sea, vol. 3. The Baltic marine biologists publication, 16c. Uppsala: Opulus press.

Snoeijs, P., Kasperovičienė, J. eds. 1996. Intercalibration and distribution of diatom species in the Baltic Sea, vol. 4. The Baltic marine biologists publication, 16d. Uppsala: Opulus press.

Snoeijs, P., Balashova, N. eds. 1998. Intercalibration and distribution of diatom species in the Baltic Sea, vol. 5. The Baltic marine biologists publication, 16e. Uppsala: Opulus press.

Stančikaitè, M., Daugnora, L., Hjelle, K., Hufthammer, A.K., 2009. The environment of the Neolithic archaeological sites in Šventoji, Western Lithuania. Quaternary international, 207(1-2), 117-129.

Tavast, E., 2000. Subfossil molluscs shells of the Baltic Sea and the possibilities of their usage in the stratigraphy and correlation of the Baltic Sea sediments. Geologos, 5, 31-40.

Van Dam, H., Mertens, A., Sinkeldam, J., 1994. A coded checklist and ecological indicator values of freshwater diatoms from the Netherlands. Journal of Aquatic Ecology, 28, 117-133.

Wheeler, E. A., 2011. InsideWood - a web resource for hardwood anatomy. IAWA Journal, 32(2), 199-211. 
Ванкина, Л. В., 1970. Торфяниковая стоянка

ABBREVIATIONS

Сарнате. Рига: Зинатне.

Лозе, И. А., 1988. Поселения Каменного Века Лубанской Низины. Мезолит, Ранний и Средний Неолит. Рига: Зинатне.

\title{
ŠVENTOJI 2/4 IŠ ARČIAU - STRATIFIKUOTA AKMENS AMŽIAUS (3200-2600 CAL BC) ŽVEJYBVIETĖ LIETUVOS PAJŪRYJE
}

\author{
Gytis Piličiauskas, Giedrè Vaikutienè, Dalia Kisielienè, Aldona Damušytė, Giedrè Piličiauskienė, \\ Kęstutis Peseckas, Lukas Gaižauskas
}

\section{Santrauka}

Šventoji 2/4 yra viena iš didžiausių akmens amžiaus radimviečių, tyrinètų Lietuvos pajūryje (1 pav.). $2300 \mathrm{~m}^{2}$ plotas buvo ištirtas per 1967, 1969, 1972, 1986-1995, 1997-1998, 2002-2005 ir 2014-2015 metus (2 pav.; Rimantienè 1979; 1980; 1996a; 2005; Juodagalvis, Simpson 2000; Brazaitis 2007; Piličiauskas et al. 2012; Piličiauskienè et al. 2015; Kurilienè et al. 2016). Archeologus ji traukè geru radinių išlikimu, stratigrafija, puikiomis aplinkos tyrimų perspektyvomis. Šiame straipsnyje pristatoma $2014 \mathrm{~m}$. kasinėjimų medžiaga ir jos ịvairių laboratorinių tyrimų rezultatai.

Radimvietè yra smèlingoje Litorinos jūros terasoje, suformuotoje apie 5000 cal BC per maksimalią transgresiją, daug kur padengtoje vèliau buvusių ežerų nuosèdomis (gitija). Ji rasta Mikelio Balčiaus 1966-1967 m. melioruojant pajūrio pelkes. Radimvietès archeologinis sluoksnis yra paplitęs apie $500 \mathrm{~m}$ ilgio ir $60 \mathrm{~m}$ pločio juostoje eroziniame duburyje. $2014 \mathrm{~m}$. buvo ištirta $18 \mathrm{~m}$ ilgio ir $2 \mathrm{~m}$ pločio perkasa, orientuota statmenai duburio krantui (3, 4 pav.). Siekiant sudaryti viso duburio skersini pjūvị, kitose jo vietose perkasos ašyje išgręžti devyni gręžiniai (2, 5 pav.). Po suarta durpe perkasoje aptiktas iki $2 \mathrm{~m}$ storio ežerinių nuosėdų sluoksnis - gitija (6 pav.). Giliau buvo lagūninès ir jūrinès nuosėdos - aleuritas ir smulkus smèlis. Panaši ir gręžinių stratigrafija.

pH matavimai parode gitijoje esant vidutiniškai rūgščią aplinką, kurioje gerai išliko mediena, tačiau daug kur sunyko moliuskų kiauteliai (1 lent.). Iš išlikusių galima spręsti, kad gitija kaupèsi gèlo stovinčio arba vangiai tekančio vandens telkinyje (Unio sp., Bithynia tentaculata, Sphaerium solidum, Valvata piscinalis), o giliau esantys smèlis ir aleuritas - Litorinos jūros priekrantėje (Macoma balthica, Cardium edule, Mytilus edulis). Diatomèjų (7 pav.) ir makrobotaniniai (8 pav.; 2 lent.) tyrimai šią išvadą patvirtino, tačiau taip pat parodè, kad lagūninis ežeras susidarè laipsniškai, vis labiau nuo jūros smèlio baromis atsitveriančios įlankos vietoje. Sekliame lagūniniame ežere gausiai augo agaro riešutai.

Radimvietèje užfiksuoti 2 archeologiniai sluoksniai - A ir B, nors A pagal skirtingo tipo keramiką viršutinèje ir apatinejje jo dalyse dar gali būti skirstomas smulkiau ị A1 ir A2 horizontus (5 pav.). Apatiniame B sluoksnyje rasta smailiadugnès, organinėmis priemaišomis liesintos porètosios keramikos (anksčiau vadintos narviška), vienas beveik sveikas indas (9B, 10 pav.). Čia buvo ypač daug žuvų kaulų (11 pav.). Aukščiau buvusiame A2 horizonte taip pat aptikta porètosios keramikos, o pačiame 
viršutiniame A1 - mineralinėmis priemaišomis liesintos, plokščiadugnès Rutulinių amforų kultūros keramikos (12 pav.). Anksčiau visas A sluoksnis buvo skiriamas tik šiai kultūrai, nes kitose vietose porètosios keramikos jame buvo randama žymiai mažiau (13 pav.).

$2014 \mathrm{~m}$. perkasoje rasti 223 mediniai ir 123 keramikos radiniai (3 lent.). Kai kurios šukès buvo apvyniotos liepos (?) karna, todèl galèjo būti naudojamos kaip lengvi tinklų pasvarai (14 pav.). Daugiau tinklų pasvarų akmeniniai, kai kurie pagaminti iš smiltainio plokščių apskaldytais kraštais, tačiau dauguma - niekaip neapdirbtų. Titnago radinių buvo vos vienas - dvipolinis skaldytinis, gintaro - tik penki. Medinių kuolų rasta tik du, ir tie išvirtę. Tarp medžio radinių vyravo skiedros ir pušinès skalos, plačiai naudotos žvejybinėms užtvaroms ir bučiams gaminti (15 pav.). Kai kurie dirbiniai pagaminti iš medžio žievès (16 pav.). Rastas uosinis kaplys, dalis geldos (17 pav.), ungurių šakès (18 pav.). A2 sluoksnyje buvo lazdyno riešutų ir suanglejusių plūduriuojančiojo agaro riešutų.

Rasta daugiau nei 20000 kaulų fragmentų, tarp kurių tik 17 - laukinių žvèrių ir paukščių (4 lent.). Vyravo žuvų kaulai, kurių vos 14 buvo A1 horizonte, 311 - A2 ir apie 20000 B sluoksnyje (5 lent.). Visuose sluoksniuose vyravo karpinès žuvys, mažiau buvo sterkų ir lydekų, visai mažai - jūrinių ir migruojančių žuvų (19-20 pav.). Anksčiau buvo nustatyta, kad Šventojoje 2/4 daugiausia gaudyti ne karšiai, o didelès lydekos. Skirtingi rezultatai gauti todèl, kad tada dauguma kaulų buvo rinkta ranka, o 2014 m. - sijota su vandeniu. Dauguma karšių buvo 30-45, o sterkai ir lydekos - 30-80 cm ilgio (21-22 pav.). Galvos ir pelekų kaulai sudarè 72,3, o slanksteliai - tik 7,7 \% visų kaulų. Tai rodo, kad Šventojoje $2 / 4$ pagautos žuvys buvo darinejjamos vietoje ị vandenị išmetant nupjautas galvas, tada išgabentos ị gyvenvietes. Otai ir menkès priešistorèje galejo būti žvejojami atviroje jūroje toliau nuo kranto, tačiau Šventojoje visai nerasta tokiai žvejybai būtinų kabliukų, tad greičiausiai negausūs jūrinių žuvų kaulai čia pateko su išmėsinètų ruonių viduriais.

Šventoji 2/4 turi 43 radiokarbonines datas ir yra viena geriausiai datuotų Lietuvos akmens amžiaus vietovių (5 lent.). Tačiau nemažai šių datų yra klaidingos arba pasendintos vandens rezervuarų efektų (23 pav.). Buvo datuota 16 labai ịvairių mèginių, paimtų iš $2014 \mathrm{~m}$. perkasos. Projektuojant 7 sausuminès kilmès mėginių datas ị vieną stulpelị buvo sudarytas amžiaus-gylio modelis giliausiai erozinio kanalo vietai (24 pav.). Pagal ji, gitija duburyje kaupèsi apie 800 metų maždaug po $2,5 \mathrm{~mm}$ per metus, o archeologiniai sluoksniai ir horizontai yra datuojami taip: B - 3110/3000-3020/2930 cal BC, A 2 - 2800/2720-2720/2650 cal BC, A1 - 2720/2650$2700 / 2620$ cal BC. Šventosios $2 / 4$ radimvietė yra vienalaikè Šventosios 23 ir 26 gyvenvietėms rytiniame lagūninio ežero krante.

Nauji ir anksčiau atlikti tyrimai leidžia atkurti gamtinę ir apgyvendinimo raidą Šventojoje 2/4. Maždaug iki 5000 cal BC čia buvusi sausuma, kurios paviršių nuplovė maksimali Litorinos jūros transgresija. Vèliau sekusios regresijos metu jūros priekrantès zona virto ịlanka, tada - lagūna, apie 3500 cal BC vèl išniro iš vandens. Tuomet jūrines ir lagūnines nuosėdas perskrodè galingas vandens srautas, išskaptavęs maždaug $500 \mathrm{~m}$ ilgio, $50-60 \mathrm{~m}$ pločio ir $2,5 \mathrm{~m}$ gylio duburị. Galbūt jị sukèlè ties Būtinge buvusio ežero vanduo, staiga prasiveržęs i jūrą nauju keliu. Tačiau srovė greitai liovėsi, o duburys ir jo krantai buvo užlieti seklaus ir šilto ežero, kuriame gausiai augo vandens riešutai. Ežeras uždumblèjo ir užaugo apie 2400 cal BC.

Seniausios žmonių veiklos liekanos Šventojoje 2/4 datuojamos apie 3500 cal BC, iš karto po erozinio kanalo susidarymo. Tačiau tai tik pavieniai radiniai, o intensyvi žvejyba prasidejo vèliau, $3100 / 3000 \mathrm{cal} \mathrm{BC}$. Užlietas kanalas tapo giliausia seklaus ežero vieta, kuri traukè tiek žuvis, tiek žvejus. Žvejota tinklais, užtvaromis su bučiais, žuvys badytos šakèmis. Polinès gyvenvietès nebuvo, visi statiniai naudoti 
žvejybai. Tikètina, kad žvejybvietëje buvo ir aukojama, galbūt pilamos gyvenvietèse surinktos ir luotais atgabentos šiukšlès.

3020/2930 cal BC žvejyba liovèsi dèl nežinomų priežasčių, o ją atnaujino paskutiniai porètosios keramikos gamintojai tik po 200 metų - 2800/2720 cal BC. Netrukus, 2800/2720 cal BC, žvejybvietę perèmè neolito žvejai - Rutulinių amforų kultūros žmonès, kurie jau augino naminius gyvulius, nors žvejybos irgi neatsisakè. Tik atrodo, kad dabar jau visos žuvys gabentos i gyvenvietes - žvejybvietèje nedarinètos. Nuslūgus vandeniui ir užakus ežerui, erozinio duburio pakrantès tapo sausos, o titnago ir gintaro radiniai rodo, kad jose neolito pabaigoje apdirbdavo gintarą.

Šventoji 2/4 yra ypatinga archeologinè vietovè: ji pasakoja ne apie pastatus ir gyvenvietes, tačiau apie paskutinių medžiotojų-rinkèjų ir pirmųjų gyvulių augintojų žvejybos strategijas pajūrio regione. Ji rodo išliekant ekonomikos ir žvejybos tradicijų tęstinumą net ir iš esmès keičiantis kultūrai.

\section{LENTELIŲ SĄRAŠAS}

1 lent. Šventosios 2/4 archeologinio sluoksnio (gitijos), jūrinių nuosèdų (aleurito) ir gruntinio vandens $\mathrm{pH}$ vertès.

2 lent. Šventosios 2/4 makrobotaninių tyrimų rezultatai. Mèginių vietos pažymètos 4 pav.

3 lent. Šventosios 2/4 2014 m. perkasos archeologinių radinių, ịskaitant lazdyno riešutų kevalus ir sudegusius plūduriuojančiojo agaro riešutus, kiekiai archeologiniuose sluoksniuose ir horizontuose. ${ }^{*}$ beveik sveiko indo svoris neitrauktas.

4 lent. Šventosios 2/4 $2014 \mathrm{~m}$. perkasos žinduolių ir paukščių kaulai (pagal kultūrinius sluoksnius ir horizontus).

5 lent. Šventosios 2/4 2014 m. perkasos žuvų kaulai (pagal kultūrinius sluoksnius ir horizontus).

6 lent. Šventosios $2 / 4{ }^{14} \mathrm{C}$ datos. $2014 \mathrm{~m}$. perkasoje paimtų mèginių datos išskirtos pasvirusiu šriftu.
Kelios tos pačios šukès ir medinio dirbinio datos išskirtos pilku fonu. ${ }^{*}$ - ittarimų keliančios medienos datos, ${ }^{* *}$ - šunų, ruonių, žuvų, žmonių kaulų, taip pat suanglejusio maisto datos, pasendintos arba galinčios būti pasendintos vandens rezervuarų efektų, ${ }^{* *}$ - neabejotinai klaidingos datos.

\section{ILIUSTRACIJŲ SĄRAŠAS}

1 pav. Mezolito - bronzos amžiaus radimvietès Šventojoje. G. Piličiausko brěž.

2 pav. 1967-2015 m. archeologinių tyrimų perkasos, šurfai, gręžinių vietos Šventosios 2-6 radimvietėse. Topografinis pagrindas - pagal LIDAR duomenis. G. Piličiausko brèž.

3 pav. Šventosios 2/4 2014 m. kasinejjimai. G. Piličiausko nuotr.

4 pav. Šventosios 2/4 gamtinè (A) ir archeologinè (B) stratigrafija $2014 \mathrm{~m}$. perkasoje. Pažymètos mèginių, paimtų makrobotaniniams (MB1-9) ir diatomejų (DT1-11) tyrimams, vietos. Sausuminès kilmès mèginių kalibruotas ${ }^{14} \mathrm{C}$ amžius nurodytas kaip $95 \%$ tikimybès intervalai. G. Piličiausko brèž.

5 pav. Erozinio kanalo pjūvis egzageruotas vertikaliai 3 kartus su moliuskų rūšių bei archeologinių sluoksnių (A1, A2, B) paplitimu. G. Piličiausko brèž.

6 pav. Šventosios 2/4 stratigrafijos erozinio duburio ŠV šlaite pavyzdys $2014 \mathrm{~m}$. perkasoje. G. $P i$ ličiausko nuotr.

7 pav. Diatomejų analizès rezultatai. Mėginiai išdèstyti nuo jauniausio viršuje iki seniausio apačioje pagal stratigrafiją (žr. 4A pav.). G. Vaikutienès brëž.

8 pav. Šventojoje $2 / 4$ identifikuotų augalų rūšys, sugrupuotos $\mathfrak{i}$ tris klases pagal augimvietes. D. Kisielienès brëž.

9 pav. Šventosios 2/4 B sluoksnio ir A2 horizonto porètoji keramika. G. Piličiausko nuotr. ir pieš.

10 pav. Porètosios keramikos indas su nulūžusiu smailiu dugnu $2014 \mathrm{~m}$. perkasoje Šventojoje 2/4. G. Piličiausko nuotr. 
11 pav. Gèlavandenių žuvų kaulų sankaupa Šventosios 2/4 radimvietès B sluoksnyje. G. Piličiausko nuotr.

12 pav. Rutulinių amforų kultūros šukès iš $2014 \mathrm{~m}$. perkasos Šventojoje 2/4. G. Piličiausko nuotr. ir pieš.

13 pav. Archeologinè stratigrafija 2003 m. perkasoje Šventojoje 2/4. Viršutiniame sluoksnyje rasta 2 tipų keramikos. L. Gaižausko brèž.

14 pav. Porètosios keramikos šukès iš $2014 \mathrm{~m}$. perkasos Šventojoje 2/4 su augalinio pluošto liekanomis paviršiuje arba išgręžtose skylèse, galbūt naudotos kaip itin lengvi tinklų pasvarai. G. Piličiausko nuotr.

15 pav. Dalis žvejybinès užtvaros skydo arba bučiaus, pagaminto iš tarpusavyje liepos (?) karna sujungtų pušinių skalų ir lazdyno karčių karkaso, aptikta Šventosios 2/4 A2 horizonte. G. Piličiausko nuotr.

16 pav. Nenustatyto medžio žievè su suraižytu vidiniu paviršiumi Šventosios 2/4 A1 horizonte. G. Piličiausko nuotr.

17 pav. Uosinės geldos fragmentas Šventosios 2/4 B sluoksnyje. G. Piličiausko nuotr.

18 pav. Uosinès ungurių šakès Šventosios 2/4 A2 horizonte. G. Piličiausko nuotr.
19 pav. Žuvų iš Šventosios 2/4 A2 horizonto rūšys. G. Piličiauskienès brëž.

20 pav. Žuvų iš Šventosios 2/4 B sluoksnio rūšys. G. Piličiauskienès brëž.

21 pav. Karpinių žuvų ilgiai Šventosios 2/4 B sluoksnyje. G. Piličiauskienès brèž.

22 pav. Plèšriųjų žuvų ilgiai Šventosios 2/4 B sluoksnyje. G. Piličiauskienès brëž.

23 pav. Šventosios $2 / 4$ kalibruotos ${ }^{14} \mathrm{C}$ datos. ${ }^{*}$ ittarimų keliančios medienos datos, ${ }^{* *}-$ šunų, ruonių, žuvų, žmonių kaulų, taip pat suanglëjusio maisto datos, pasendintos arba galinčios būti pasendintos vandens rezervuarų efektų, ${ }^{\star * *}$ - neabejotinai klaidingos datos. Neabejotinai klaidingų arba įtartinų datų 95,4 \% tikimybès intervalai išskirti raudonai. G. Piličiausko brèž.

24 pav. Amžiaus-gylio modelis, sudarytas ežerinių nuosėdų storymei (gitijai) Šventojoje $2 / 4$ panaudojant sausuminès kilmès méginių iš $2014 \mathrm{~m}$. perkasos ${ }^{14} \mathrm{C}$ datas. Pažymètina, kad kultūrinių sluoksnių ir horizontų ribos netikslios dèl nedidelio keramikos tankio, o datų iš ịvairių perkasos vietų projektavimas ị vieną stulpeli galèjo lemti papildomą paklaidą. G. Piličiausko brëž. 